Michał Pawikowski

\title{
INTERPRETACJA METAFORY TRIUMFU W 2 KOR 2:14 JAKO PROBLEM METODOLOGICZNY*
}

Drugi List do Koryntian ${ }^{1}$ to pismo utrzymane $\mathrm{w}$ tonie polemicznym, poprzez które apostoł Paweł próbuje załagodzić konflikt pomiędzy nim samym a lokalną wspólnotą chrześcijańską. Początkowe wyjaśnienia na temat ostatnich kontrowersyjnych zmian w podróży misyjnej autor wieńczy zagadkowym dziękczynieniem:

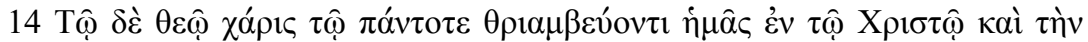

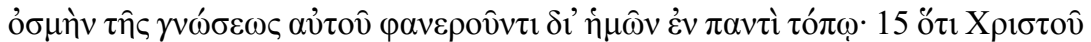

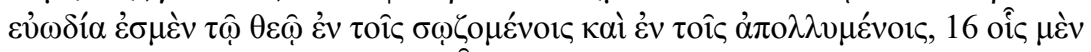

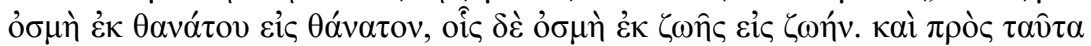

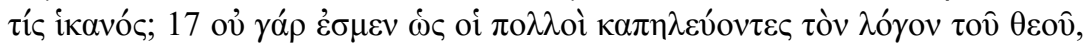

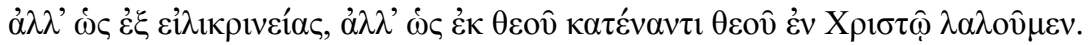

Niniejszy artykuł powstał na podstawie pracy licencjackiej pt. Interpretacja metafory triumfu w 2Kor 2:14. Studium metodologiczne (Torun 2020), napisanej pod kierunkiem prof. dr. hab. Przemysława Nehringa.

${ }^{1}$ Cytaty greckie za: Novum Testamentum Graece, wyd. 28, B. Aland, K. Aland, J. Karavidopoulos, C. M. Martin, B. M. Metzger, H. Strutwolf (wyd.), Stuttgart 2012. Cytaty polskie (jeśli nie podano inaczej) za: Pismo Święte Starego i Nowego Testamentu w przekładzie z języków oryginalnych, opracował zespół biblistów polskich z inicjatywy Benedyktów Tynieckich, Poznań 2005. 
14 Lecz dzięki niech będą Bogu za to, że w Chrystusie zawsze wiedzie nas $\mathrm{w}$ pochodzie triumfalnym i w każdym miejscu roznosi przez nas woń Jego poznania; 15 ponieważ jesteśmy miłym zapachem Chrystusa dla Boga wśród tych, którzy dostępują zbawienia oraz wśród tych, którzy giną; 16 dla jednych wonią ze śmierci ku śmierci, dla drugich zaś wonią z życia ku życiu. A do tego któż jest zdatny? 17 Nie jesteśmy bowiem jak wielu, którzy kupczą słowem Bożym, ale mówimy tak, jak ze szczerości, jak z Boga [i] wobec Boga w Chrystusie. $^{2}$

Apostoł przeplata tu zasadniczo trzy motywy: triumfu, zapachu oraz śmierci i życia. Na podstawie literatury przedmiotu widać, że interpretacja tych metafor sprawia egzegetom duże trudności, przede wszystkim dlatego, że nie jest jasne, do jakich zjawisk kulturowych się one odwołują. Wyjaśniane są m.in. w odniesieniu do rzymskich pochodów triumfalnych, greckich procesji religijnych, żydowskiego kultu świątynnego czy nawet tzw. mistyki merkawy, brak tu jednak zdecydowanego konsensusu.

Powyższy tekst stanowi dobry punkt wyjścia do rozważań na temat następującego problemu metodologicznego: w jaki sposób interpretować metafory bazujące na jakimś dodatkowym - niejasnym dla nas - podłożu, np. takie, które zawierają nawiązanie intertekstualne lub odniesienie do tła kulturowego? Co zrobić z alternatywnymi interpretacjami? Niniejszy artykuł pochyla się nad tym właśnie zagadnieniem. Jego celem jest zaprezentowanie metodologii, która w odniesieniu do omawianego tekstu 2 Kor 2:14 umożliwia: a) przeprowadzenie procesu interpretacji konkretnej metafory, b) określenie, czy dany sposób rozumienia metafory jest prawdopodobny, oraz c) porównanie prawdopodobieństwa konkurencyjnych interpretacji.

\section{Metodologia}

Opierając się na klasycznych definicjach możemy powiedzieć, że na metaforę składają się dwa elementy: określenie metaforyczne oraz to, co jest określane metaforycznie, pomiędzy którymi zachodzi podobieństwo. ${ }^{3} \mathrm{~W}$ przypad-

${ }^{2}$ Przekład własny.

${ }^{3}$ H. Lausberg, Retoryka literacka. Podstawy wiedzy o literaturze, Bydgoszcz 2002, s. 316. 
ku 2 Kor 2:14 mamy do czynienia z sytuacją, gdy niezrozumiałe jest określenie metaforyczne, a co za tym idzie, również to, co jest określane metaforycznie. Nasza metodologia musi więc pozwalać na interpretację obu tych płaszczyzn, tj. rozpocząc od ustalenia literalnego sensu tekstu w oparciu o dane zewnętrzne (inne źródła), a następnie ustalić jego znaczenie przenośne. ${ }^{4}$

\subsection{Metodologia Christopha Heiliga}

Wydaje się, że te wymogi mogłyby spełniać kryteria opracowane przez Richarda Haysa. Jest to siedem kryteriów służących do oceny bardzo subtelnych nawiązań do Starego Testamentu (tzw. echa) w listach Pawłowych. ${ }^{6}$ Jednakże w ostatnim czasie ta metodologia spotkała się z zasadną krytyką Christopha Heiliga. Uporządkował on kryteria Haysa i przedstawił nowe podejście oparte na twierdzeniu Bayesa - najpierw w odniesieniu do przypuszczalnej polemiki z ideologią cesarską w listach Pawła, następnie względem problemu interpretacji 2 Kor 2:14. ${ }^{7}$ Podejście Heiliga będzie podstawą proponowanej tu metody.

Wspomniana metodologia zakłada podejście do egzegezy tekstu jako do oceny prawdopodobieństwa hipotez (gdzie hipotezą jest proponowany sposób rozumienia danego tekstu). Jej podstawę teoretyczną stanowi twierdzenie Bayesa w następującej postaci:

${ }^{4}$ Idealna metodologia powinna również sprawdzać, czy zachodzi dostateczny związek podobieństwa między elementami metafory - nikłe podobieństwo stanowiłoby argument przeciwko takiej interpretacji tekstu. Nie sposób jednak wskazać precyzyjnych kryteriów, którymi moglibyśmy się wówczas posłużyć. Tę kwestię lepiej jest więc pozostawić intuicji egzegety i nie ujmować jej w formalne ramy.

${ }^{5}$ R. B. HAYs, Echoes of Scripture in the Letters of Paul, New Haven - London 1989, s. 29-32.

${ }^{6}$ Niektórzy badacze opierają się na nich np. przy analizie tekstów, w których Paweł przypuszczalnie polemizuje z ideologią cesarską, zob. N. T. Wright, Paul in Fresh Perspective, Minneapolis 2005, s. 61; N. ELLIOTT, The Arrogance of Nations: Reading Romans in the Shadow of Empire, Minneapolis 2008, s. 22.

${ }^{7}$ C. Heilig, „Methodological considerations for the search of counter-imperial «echoes» in Pauline literature", [w:] J. A. Dunne, D. Batovici (red.), Reactions to Empire. Proceedings of Sacred Texts in Their Socio-Political Contexts, Tübingen 2014, s. 84-85; IDEM, Paul's Triumph. Reassessing 2 Corinthians 2:14 in Its Literary and Historical Context [= Biblical Tools and Studies 27], Leuven - Paris - Bristol 2017, s. 6-10. 


$$
p(H \mid E)=\frac{p(E \mid H) \times p(H)}{p(E)}
$$

gdzie:

- $\mathrm{p}(\mathrm{H} \mid \mathrm{E})$ oznacza prawdopodobieństwo hipotezy $\mathrm{H}$ wobec wystąpienia zdarzenia E (w naszym przypadku - wobec sformułowania przez Pawła tekstu 2 Kor 2:14-17);

- p(E|H) oznacza prawdopodobieństwo wystąpienia zdarzenia E przy założeniu hipotezy $\mathrm{H}$;

- $\mathrm{p}(\mathrm{H})$ oznacza prawdopodobieństwo hipotezy $\mathrm{H}$ bez brania pod uwage zdarzenia $\mathrm{E} ;{ }^{9}$

- p(E) oznacza prawdopodobieństwo wystąpienia zdarzenia E w ogóle (w naszym przypadku $\mathrm{z}$ góry przyjmujemy, że $\mathrm{p}(\mathrm{E})=1, \mathrm{tj}$. $\mathrm{z}$ góry przyjmujemy za prawdę, że Paweł spisał omawiany przez nas tekst).

Powyższe twierdzenie opisane wzorem matematycznym można przekształcić w praktyczne kryteria, czy też pytania, które należy zadawać podczas egzegezy tekstu: ${ }^{10}$

I. Prawdopodobieństwo na podstawie tła, $\mathbf{p}(\mathrm{H})$ - czy danego znaczenia tekstu moglibyśmy się spodziewać na podstawie samego kontekstu? Należy to sprawdzać w dwóch krokach:

a) Świadectwo zewnętrzne - czy dane znaczenie tekstu jest prawdopodobne, jeśli weźmie się pod uwagę m.in. chronologię i obszar działalności autora oraz charakterystykę jego adresatów (np. czy Paweł mógł wiedzieć, jak wyglądała rzymska procesja triumfalna)?

\footnotetext{
${ }^{8} \mathrm{~W}$ związku z tym, że nie odnosimy się tu do zdarzenia przewidywanego (do czego zwykle używane jest to twierdzenie), ale do zdarzenia z przeszłości, zdaniem C. Heiliga najlepiej myśleć o tej wartości po prostu jako o zaufaniu w prawdziwość hipotezy H, zob. HeILIG, „Methodological considerations” (cyt. w przyp. 7), s. 80-81.

${ }^{9} \mathrm{p}(\mathrm{H})$ nie rozpatrujemy w izolacji, ale odwołujemy się do już posiadanej wiedzy zewnętrznej. Oceniając np. prawdopodobieństwo hipotezy, według której Juliusz Cezar cytuje Szekspira, sprawdzamy, w jakich latach żyli Cezar oraz Szekspir. Twierdzenie Bayesa uzupełnione o wiedzę uprzednią $\mathrm{P}$ wyglądałoby więc następująco: $\mathrm{p}(\mathrm{H} \mid \mathrm{E} \& \mathrm{P})=\mathrm{p}(\mathrm{E} \mid \mathrm{H} \& \mathrm{P}) \times \mathrm{p}(\mathrm{H} \mid \mathrm{P}) / \mathrm{p}(\mathrm{E} \mid \mathrm{P})$, zob. HeILIG, „Methodological considerations” (cyt. w przyp. 7), s. 80-81.

${ }^{10}$ Hellig, Paul's Triumph (cyt. w przyp. 7), s. 8-9.
} 
b) Świadectwo wewnętrzne - czy danego znaczenia tekstu spodziewalibyśmy się na podstawie szerszego kontekstu pism tego samego autora oraz bezpośredniego kontekstu literackiego naszego fragmentu (np. czy Paweł już gdzieś przywołuje podobną metaforę)?

II. Potencjał wyjaśniający, p(E|H) - czy założenie danego znaczenia dobrze wyjaśnia sposób sformułowania tekstu (np. czy staje się on wówczas jaśniejszy, czy raczej odczytanie go w ten sposób jest karkołomne)?

Aby hipoteza została uznana za prawdopodobną, obydwa kryteria muszą zostać spełnione, wszystkie pytania muszą się spotkać z pozytywną odpowiedzią. ${ }^{11}$ Hipoteza bowiem może doskonale wyjaśniać tekst, ale jeśli nie jest prawdopodobna $\mathrm{w}$ kontekście historycznym i literackim, nie powinna zostać przyjęta - i na odwrót - hipoteza może bazować na bardzo prawdopodobnym kontekście historycznym i literackim, jeśli jednak odczytanie pod jej kątem tekstu jest karkołomne, również nie może zostać przyjęta. ${ }^{12}$

\subsection{Proponowana metodologia}

Zaprezentowana wyżej metodologia doskonale nadaje się do oceny wszelkich hipotez, które interpretują jedno zjawisko wobec drugiego, np. znaczenie tekstu wobec sposobu jego sformułowania. Metafora jednak okazuje się bardziej skomplikowanym przedmiotem badania, w pewnym sensie posiada bowiem nie jeden, a dwa poziomy znaczeniowe - literalny oraz metaforyczny (określenie metaforyczne i to, co metaforycznie określane). W przypadku 2 Kor 2:14 metafora jest niejasna na obu tych poziomach. Mając to na uwadze, interpretację należałoby wówczas przeprowadzić dwu-

\footnotetext{
${ }^{11}$ Innymi słowy, wartość zarówno $\mathrm{p}(\mathrm{E} \mid \mathrm{H})$, jak i p(H) musi wynosić 1.

${ }^{12}$ Oczywiście w humanistyce możemy sobie wyobrazić wyjątki od tej reguły. Wypowiedź nie spełniałaby kryterium prawdopodobieństwa na podstawie tła, gdyby autor odnosił się do zjawiska, które jest nam nieznane z powodu niedoboru źródeł. Podobnie z potencjałem wyjaśniającym - autor już pierwotnie mógł się wypowiedzieć w sposób niejasny lub użyć bardzo nietypowego sformułowania. Należy więc rozważyć i taką możliwość, jeśli są ku temu przesłanki. Mimo to jednak powinniśmy po pierwsze opierać się na tym, co wiemy, oraz po drugie, zakładać, że autor zamierzał być zrozumiany przez swoich adresatów.
} 
krotnie - raz interpretując tekst na poziomie literalnym i raz na metaforycznym. ${ }^{13}$ Niestety taki proces dowodzenia byłby bardzo długi i w dużej mierze nieintuicyjny. Ponadto, o ile wymienione wcześniej kryteria dają się zastosować przy interpretacji sensu literalnego, o tyle trudno ich użyć przy samym sensie metaforycznym.

Biorąc pod uwagę powyższe problemy, wydaje się, że najlepiej będzie użyć metodologii Heiliga na tym polu, na którym będzie to najbardziej efektywne do interpretacji tekstu na poziomie literalnym. Dzięki temu będzie można w sposób metodyczny określić np. to, do jakiego zjawiska kulturowego odwołuje się metafora. Dopiero spełnienie tego warunku pozwoli na dalszą interpretację tekstu na poziomie metaforycznym. ${ }^{14} \mathrm{~W}$ tym jednak przypadku nie sposób wyszczególnić stałych, obiektywnych kryteriów, które egzegeta miałby stosować punkt po punkcie, by dojść do właściwej interpretacji tekstu. ${ }^{15}$ Przeprowadzenie tego rodzaju interpretacji zależy w dużej mierze od intuicji i osobistego warsztatu badacza, stąd powinno się pozostawić mu miejsce na pewną dowolność. A zatem interpretacja tekstu na poziomie metaforycznym dokonywana będzie z użyciem klasycznej metody egzegezy historyczno-literackiej.

Proponowaną tu metodologię będziemy stosować również $\mathrm{w}$ innym zakresie, niż czyni to Christoph Heilig. W podejściu tego autora celem jest przeprowadzenie całościowej egzegezy tekstu - jeden rozbudowany proces dzieli on na etapy, w których uwzględnia wszystkie alternatywne hipotezy znaczenia: zaczynając od świadectwa zewnętrznego ocenia pod tym kątem wszystkie hipotezy, później niezależnie analizuje świadectwo wewnętrzne,

\footnotetext{
${ }^{13}$ Można oczywiście wyrazić wątpliwość, że skoro na zasadnicze znaczenie metafory składają się oba poziomy, dlaczego nie możemy potraktować ich razem, jak uczynił to C. Heilig? W końcu interpretując jeden, nie sposób uciec od drugiego. Nie wydaje się to nierozsądne, jednak z drugiej strony może prowadzić do istotnych problemów, np. możliwy jest przypadek, kiedy hipoteza dobrze interpretuje tekst na poziomie literalnym, ale źle na poziomie metaforycznym - stosując niezmienioną metodologię Heiliga trudno byłoby to dostrzec.

${ }^{14}$ Oczywiście nie zawsze da się uniknąć odwołania do drugiego poziomu znaczeniowego. Główne rozważania na temat sensu metaforycznego powinniśmy zamieścić jednak w punkcie mu poświęconym.

${ }^{15}$ Mimo nieco odmiennego podejścia metodologicznego, podobnie zauważa również HeILIG, Paul's Triumph (cyt. w przyp. 7), s. 246-247: „Of course, in moving from lexical semantics in general to specific pragmatics of Paul's triuph metaphor, we leave the territory that can be analysed in relatively 'objecive' manner with regard to material from ancient sources".
} 
a następnie znów ocenia wszystkie hipotezy pod kątem potencjału wyjaśniającego. Nasze podejście będzie odmienne pod tym względem, że o ile dla Christopha Heiliga zasadniczym przedmiotem badania jest tekst, dla nas będzie nim hipoteza znaczenia tekstu. Będziemy więc analizować hipotezy jako samodzielne całości. Zamiast jednej długiej analizy, przeprowadzimy kilka krótkich dla każdej hipotezy osobno. Dzięki temu metodologia zyska nowe zastosowania, umożliwi np. weryfikację pojedynczych hipotez znaczenia lub łatwe porównanie prawdopodobieństwa jedynie wybranych sposobów rozumienia tekstu. ${ }^{16}$

Cały proces interpretacji tekstu będzie więc wyglądał następująco:

\section{Przedstawienie hipotezy;}

II. Interpretacja tekstu na poziomie literalnym: ${ }^{17}$

a) Prawdopodobieństwo na podstawie tła:

Świadectwo zewnętrzne;

Świadectwo wewnętrzne;

b) Potencjał wyjaśniający;

III. Interpretacja tekstu na poziomie metaforycznym.

Zastosowanie kryteriów Heiliga pozwoli wówczas na odrzucenie interpretacji, które mają niedostateczne podstawy. Te, które przejdą ten test, muszą już zostać ocenione w bardziej intuicyjny sposób, gdyż nie wyszczególnia się precyzyjnych kryteriów dla punktu trzeciego.

\section{WYBÓR METAFORY DO ANALIZY}

Wybór przedmiotu analizy musi zostać w tym przypadku poczyniony bardzo ostrożnie, gdyż wydaje się, że poszczególne metafory w omawianej

${ }^{16}$ Chcąc tą metodą dokonać wyczerpującej analizy, należałoby po prostu przeprowadzić ten proces kolejno względem wszystkich możliwych hipotez. Wówczas ujawnia się pewna zaleta tego podejścia - w przypadku pojawienia się nowej hipotezy nie trzeba przebudowywać całego wywodu, wystarczy bowiem dodać do analizy jeden element więcej.

${ }^{17}$ Należy zauważyć, że niespełnienie kryteriów punktu II każe uznać hipotezę za nieprawdopodobną, stąd cały proces może się zakończyć już w tym miejscu. 
perykopie są w jakiś sposób połączone. Po pierwsze, już sam fakt, że w 2:14 Paweł zestawia obok siebie dwie bardzo nietypowe metafory (triumfu i zapachu), jest przesłanką za tym, że chce słownie wymalować przed czytelnikiem złożony obraz. Po drugie, Paweł wprowadza te metafory w sposób bardzo podobny składniowo. Zdanie $\mathrm{z}$ wersetu 14 można bowiem podzielić na dwie zasadnicze części, w których zauważalny jest ciąg: imiesłów - zaimek osobowy - $\grave{\varepsilon} v$ z zależnym rzeczownikiem. Podczas głośnej lektury po obu zjawiskach naturalnie następuje pauza, przez co można usłyszeć regularność:

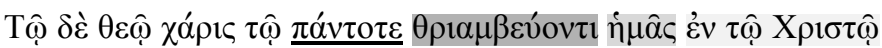

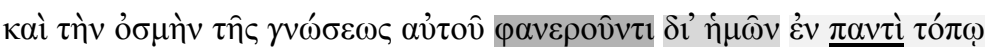

Po trzecie, podobieństwa leksykalne wskazują, że obie metafory mogą odnosić się do tej samej kwestii używając jedynie innych obrazów. Główny

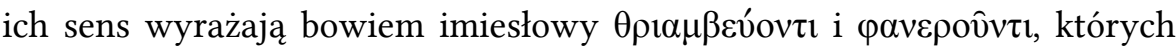
znaczenie jest w pewien sposób zbliżone, obydwa odnoszą się do ukazywania czegoś publicznie - czy to w odniesieniu do jeńców lub łupów podczas triumfu w przypadku $\theta \rho \imath \alpha \mu \beta \varepsilon v ́ \omega$, czy też bardziej ogólnie w przypadku

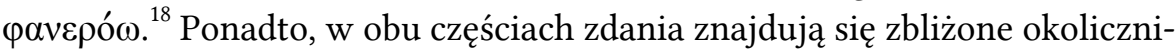

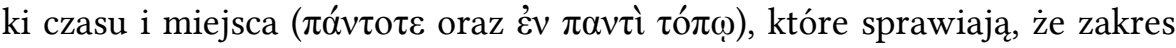
czynności jest taki sam. W obu pojawiają się również zaimki osobowe w pierwszej osobie liczby mnogiej ( $\dot{\eta} \mu \hat{\alpha} \varsigma$ i $\dot{\eta} \mu \hat{\omega} v)$, co wskazuje na to, że oba działania dotyczą tej samej osoby.

Ponieważ błędem byłoby rozpatrywanie w izolacji metafory, której znaczenie jest uzależnione od innej, musimy dokładniej zastanowić się nad ich wzajemną relacją. Na odpowiedź mogą naprowadzać zaimki osobowe, które w obu metaforach stawiają osobę mówiącą w nieco innej roli - Bóg wiedzie

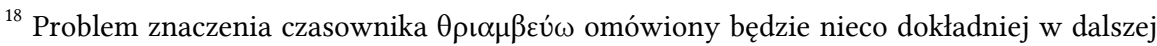
części artykułu, zob. HeIlig, Paul's Triumph (cyt. w przyp. 7), s. 99-101; pavepó $\omega:$ W. Bauer, W. F. Arndt, W. F. Gingrich, F. W. Danker, A Greek-English Lexicon of the New Testament and Other Early Christian Literature, Chicago - London 2000, s. 1048. W kwestii powiązania imiesłowów podobnie zauważa M. J. HarRIs, The Second Epistle to the Corinthians. A Commentary on the Greek Text [The New International Greek Testament Commentary Series], Grand Rapids - Michigan 2005, s. 246: „Since $\varphi \alpha v \varepsilon \rho o v v \tau \imath$ is coordinate with $\theta \rho 1 \alpha \mu \beta \varepsilon v ́ o v \tau 1$, both being present participles describing God's continous action, it is fair to assume that the 'odor' should be understood against the same background as v. 14a, the Roman triumph".
} 
„nas” (í $\mu \hat{\alpha} \varsigma)$, i roznosi woń „przez nas” ( $\delta$ ' $\dot{\eta} \mu \hat{\omega} v)$. Wydaje się więc, że pierwsza czynność, tj. prowadzenie w procesji, jest czynnością główną, której efektem jest druga (roznoszenie woni). Wówczas Paweł użyłby dwóch metafor nie po to, by po prostu powtórzyć to samo innymi słowami, ale raczej ukazać tę samą sprawę z dwóch różnych perspektyw. Czy jednak autor kontynuuje ten sam obraz $\mathrm{w}$ wersetach 2:15-2:16? W odniesieniu do metafory zapachu zachodza tu istotne zmiany. W 2:14 Paweł używa rze-

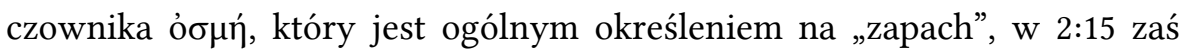
używa $\varepsilon \bigcup j \omega \delta i ́ \alpha$, co oznacza konkretnie „przyjemny zapach”. ${ }^{19}$ Woń zmienia swoją funkcję, gdyż w 2:14 skierowana jest w kierunku ludzi, by umożliwić im poznanie Boga ( się ku Bogu ( $\tau \hat{̣} \theta \varepsilon \hat{\varphi})$. Zmienia się ponadto rola Pawła - w 2:14 woń roznosi się poprzez niego ( $\left.\delta \imath^{\prime} \dot{\eta} \mu \hat{\omega} v\right)$, w 2:15 natomiast on sam jest zapachem ( $\varepsilon \dot{v} \omega \delta \delta^{\prime} \alpha$ $\dot{\varepsilon} \sigma \mu \varepsilon ́ v)$. Co ważne, dalej autor nie powraca już do słownictwa związanego $\mathrm{z}$ triumfem. Teraz łączy metaforę zapachu z określeniami, które mają słabszy wymiar metaforyczny - mówi o tych, którzy dostępują zbawienia lub

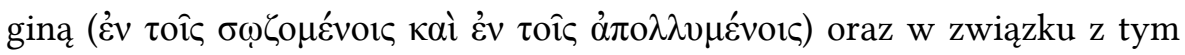

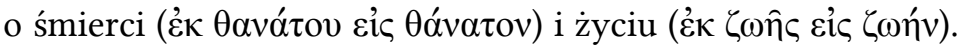

$\mathrm{Na}$ podstawie powyższych obserwacji możemy sądzić, że perykopa zawiera serię wzajemnie ze sobą powiązanych metafor. ${ }^{20}$ Najpewniej to czasownik $\theta \rho \iota \alpha \mu \beta \varepsilon v ́ \omega$, jako pierwszy w kolejności, ustanawia metaforę nadrzędną, z której następnie wypływa metafora zapachu - obydwie mieszczą się w ramach jednego, szerszego obrazu. Jednak w związku z tym, że w 2:1516 Paweł nie odwołuje się już do triumfu, musielibyśmy uznać, że później oddala się już nieco od początkowej metafory i poprzez odwołanie do śmierci i życia zaczyna mówić bardziej wprost o swojej służbie. ${ }^{21}$ Metafora trium-

\footnotetext{
${ }^{19}$ Znaczenie ỏ $\sigma \mu \eta ́$ : W. Bautr, W. F. Arndt, W. F. Gingrich, F. W. Danker, A Greek-English Lexicon

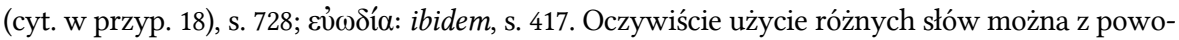
dzeniem wytłumaczyć chęcią uniknięcia powtórzeń, ponieważ w 2:17 Paweł powraca do ỏ

${ }^{20}$ Czyli to, co klasyczne dzieła retoryczne określają jako alegorię, zob. Rhetorica ad Herrenium 4.34; Pseudo-Longinus, De sublimitate 32.5. Ze względu na to, że Paweł dalej zaczyna mówić bardziej wprost, byłaby to wówczas tzw. alegoria częściowa, zob. Kwintylian, Institutio oratoria 8.6.47.

${ }^{21} \mathrm{Z}$ drugiej strony, metafora zapachu bez wątpienia dominuje (przynajmniej pod względem liczby odwołań), szybko spychając obraz triumfu na dalszy plan. Jeśli na podstawie stu-
} 
fu $(\theta \rho 1 \alpha \mu \beta \varepsilon u ́ \omega)$ wydaje się najbardziej rozsądnym przedmiotem analizy jest ona najmniej zależna znaczeniowo od pozostałych, a przy tym jej zrozumienie jest kluczowe dla zrozumienia całości obrazu.

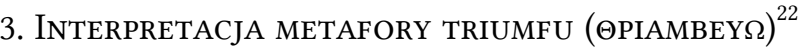

\subsection{Rzymska procesja triumfalna}

Zdecydowana większość komentatorów przyjmuje, że czasownik $\theta \rho ı \alpha \beta \varepsilon v \omega_{\omega}$ w 2 Kor 2:14 nawiązuje do rzymskiej ceremonii triumfu (gr. $\theta$ pía $\mu \beta$ oc, lat. triumphus). Mimo to, nie zawsze rozumieją go tak samo. $\mathrm{W}$ toku długiej dyskusji pojawiło się kilka opcji, które nadają wyrażeniu $\theta \rho ı \mu \beta \varepsilon v ́ o v \tau \imath ~ \eta j \mu \hat{\alpha}$ z z 2:14 skrajnie różny wydźwięk: a) „który pozwala nam triumfować”; ${ }^{23}$ ) „który prowadzi nas w triumfie” (jak wódz prowadzi swoich żołnierzy); ${ }^{24} \mathrm{c}$ ) „który prowadzi nas $\mathrm{w}$ triumfie” (jako jeńców na

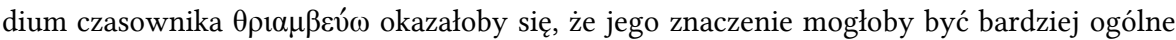
i nie musi tu wcale wyrażać metafory, musielibyśmy uznać, że to raczej wokół obrazu zapachu oscyluje cały nasz tekst. Należy odnotować, że kilku autorów proponowało właśnie takie rozumienie $\theta p i \alpha \mu \beta \varepsilon v ́ \omega$ jako „ujawniać”, „czynić znanym”, „rozsławiać” itp.: F. FIELD, Notes on the Translation of the New Testament, Cambridge 1899, s. 181-182; R. B. EGAN, „Lexical eviden-

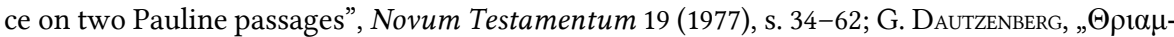

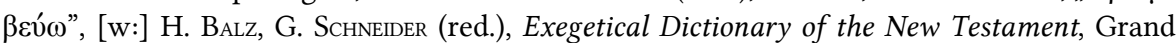
Rapids 1994, s. 155-156. To podejście jest jednak słusznie krytykowane za brak odpowiedniego poparcia źródłowego np. w: Hellig, Paul’s Triumph (cyt. w przyp. 7), s. 107-111.

${ }^{22}$ Należy zaznaczyć, że przedstawione dalej kwestie szczegółowe w dużej mierze pokrywają się z: HeILIG, Paul's Triumph (cyt. w przyp. 7). Punkt 3.1. jest bezpośrednim zreferowaniem interpretacji Christopha Heiliga w kluczu obranym w poprzednim rozdziale. W przypadku 3.2. i 3.3. nasze ustalenia zostały opracowane w dużej mierze niezależnie, jednak w większości pokrywają się z wnioskami tego autora. Niniejszy rozdział należy traktować jedynie jako ilustrację poprzednich rozważań metodologicznych, niż oryginalne omówienie zagadnień szczegółowych - w tej kwestii musimy odesłać czytelnika do znakomitego Paul's Triumph.

${ }^{23}$ Ten sposób rozumienia 2 Kor 2:14 spopularyzowały głównie thumaczenia Biblii, przede wszystkim klasyczne angielskie tłumaczenie King fames Version, na gruncie polskim zaś Biblia Tysiąclecia. Nie są nam jednak znane żadne opracowania egzegetyczne preferujące tę opcję.

${ }^{24}$ Ten sposób rozumienia preferowano $\mathrm{w}$ wiekowych już dzisiaj komentarzach, np. J. CAlvin, Commentary on the Epistles of Paul the Apostle to the Corinthians, t. 2, Edinburgh 1848, s.157-158; M. Luther, Werke, t. 15, Weimar 1899, s. 655. Sporadycznie pojawia się także 
śmierć) ${ }^{25}$ d) „który celebruje triumf po zwycięstwie nad nami”. ${ }^{26}$ Pierwsze dwie - „pozytywne” - opcje należą już do odległej historii interpretacji, od dawna są powszechnie odrzucane, gdyż nie posiadają żadnych paralel w literaturze starożytnej. Kolejne dwie - „negatywne” - do niedawna były przedmiotem nierozstrzygniętej dyskusji, gdyż brakowało prawdziwie kompletnego i poprawnego metodologicznie opracowania tematu. Potrzebę tę zaspokoił Christoph Heilig, który przeprowadził rewizję dotychczasowych propozycji oraz dokładną analizę wszystkich przykładów użycia czasownika $\theta \rho 1 \alpha \mu \beta \varepsilon u ́ \omega \mathrm{w}$ korpusie $T L G$, by ustalić jego pole semantyczne (w sensie przechodnim). ${ }^{27}$ Ostateczna definicja brzmi następująco:

to cause sb. or sth. to move (before oneself) in a triumphal procession in order to display sb. or sth. to the watching crowd. ${ }^{28}$

W samym polu semantycznym czasownika nie mieści się więc kwestia tego, by obiekt wiedziony był na śmierć lub został zwyciężony. Mimo to jednak brak jest przesłanek, by obiekt mógł występować w jakiejś bardziej „pozytywnej” roli. ${ }^{29}$ Faktem jest, że w standardowym użyciu przechodniego $\theta \rho 1 \alpha \mu \beta \varepsilon v ́ \omega$ jego dopełnienie dotyczy jeńców prezentowanych w pochodzie, w niewielu przypadkach zaś łupów wojennych. Niemałym wyzwaniem dla egzegety będzie zinterpretowanie pod tym kątem 2 Kor 2:14, gdyż owym jeńcem musiałby być sam apostoł Paweł, tym zaś, który go wiedzie - Bóg.

w opracowaniach bardziej współczesnych, przy czym ich autorzy często zdają sobie sprawę, że interpretacja ta nie posiada wystarczających podstaw, zob. np. C. K. BARretT, A Commentary on the Second Epistle to the Corinthians, London 1973, s. 98.

${ }^{25}$ L. Williamson, „Led in triumph. Paul's use of thriambeuo”, Interpretation 22 (1968), s. 317332; S. J. Hafemann, Suffering and the Spirit. Paul's Defence of His Ministry in II Corinthians 2:14-3:3 [Paternoster Biblical Monographs], Milton Keynes - Colorado Springs - Hyderabad 2000, s. $16-34$

${ }^{26}$ C. BReytenbach, „Paul's proclamation and God's «thriambos» (Notes on 2 Corinthians 2:14-16b)", Neotestamentica 24 (1990), s. 257-271.

${ }^{27}$ HeILIG, Paul's Triumph (cyt. w przyp. 7), s. 25-116.

${ }^{28}$ Ibidem, s. 101.

${ }^{29}$ Ibidem, s. 96. 


\section{a) Interpretacja tekstu na poziomie literalnym}

Prawdopodobieństwo na podstawie tła (świadectwo zewnętrzne): Podstawową kwestią jest to, czy triumf rzymski mógł być zjawiskiem znanym Pawłowi i jego adresatom. Komentatorzy bardzo rzadko zadają sobie to pytanie, najczęściej z góry zakładając ogólną świadomość na temat tej ceremonii wśród mieszkańców Cesarstwa Rzymskiego. Oczywiście, triumf jako wydarzenie powtarzające się regularnie na przestrzeni wielu wieków mógł zadomowić się w takiej ogólnej świadomości - w końcu w okresie od założenia Rzymu do rządów Wespazjana zarejestrowano aż 320 triumfów. $^{30}$ $Z$ drugiej strony zdecydowana większość tych ceremonii przypada na okres republikański, natomiast od czasów pryncypatu Augusta triumf staje się niemal wyłącznym przywilejem cesarza i przez to jego częstotliwość drastycznie się zmniejsza. ${ }^{31} \mathrm{Na}$ czasy panowania dynastii julijsko-klaudyjskiej od Augusta aż do Galby przypada już tylko siedem triumfów. ${ }^{32}$ Być może lepszym pytaniem byłoby więc to, czy Paweł i jego adresaci mogli wiedzieć o jakimś konkretnym wydarzeniu tego rodzaju. Chronologicznie najbardziej pasuje tu triumf Klaudiusza z 44 r. n.e. po zwycięstwie w Brytanii ${ }^{33}$ - przypada on wprost na okres działalności misyjnej apostoła, dostatecznie długo przed powstaniem 2 Kor. Oczywiście Paweł nie mógł osobiście oglądać tej ceremonii. Czy jest jednak prawdopodobne, by miał o niej jakieś wyobrażenie na podstawie innych źródeł? Możemy wziąć pod uwagę kilka pośrednich przesłanek. Zwycięstwo i triumf Klaudiusza odbiły się wówczas szerokim echem zarówno na poziomie politycznym,${ }^{34}$ jak i w sztuce, poprzez łuki

\footnotetext{
${ }^{30}$ Hafemann, Suffering and the Spirit (cyt. w przyp. 25), s. 22.

${ }^{31}$ K. BalbuZA, Triumfator. Triumf $i$ ideologia zwycięstwa $w$ starożytnym Rzymie epoki cesarstwa [= Poznańskie Studia Historyczne 11], Poznań 2005, s. 45-52.

${ }^{32}$ Ibidem, s. 239-240.

${ }^{33}$ Na okres bliski życiu Pawła przypada jeszcze triumf Germanika w roku 9 n.e. po zwycięstwie w Panonii i Dalmacji. Nawiązanie do tego wydarzenia jest jednak dużo mniej prawdopodobne ze względu na oddalenie w czasie - jeśli Paweł w ogóle już wtedy żył, był małym dzieckiem.

${ }^{34}$ Poszczególne miasta i prowincje Cesarstwa z okazji triumfu Klaudiusza przesyłały cesarzowi złote wieńce, a namiestnicy prowincji otrzymali przywilej przyjazdu do Rzymu w celu oglądania ceremonii, zob. BalbuzA, Triumfator (cyt. w przyp. 31), s. 86.
} 
triumfalne, rzeźby oraz przedstawienia na monetach - nie tylko w Italii i Galii, ale również w Grecji. ${ }^{35} \mathrm{Z}$ samego Koryntu pochodzi inskrypcja mająca poświadczać kult tzw. bogini Victoria Britannica w ramach lokalnego kultu cesarskiego. ${ }^{36}$ Poza tym, bardzo interesujące, choć zupełnie spekulatywne jest przypuszczenie, że Paweł mógłby mieć dostęp do wiadomości zasłyszanych od samych mieszkańców Rzymu - np. od Pryscylli i Akwili, którzy według Dz 18:2 mieli przybyć do Koryntu krótko po edykcie Klaudiusza o wydaleniu Żydów z Rzymu i spotkać się tam z Pawłem. Jeśli jednak mówimy nie o wiedzy na temat samego faktu triumfu, ale przebiegu procesji, najważniejszym źródłem dla Pawła zapewne byłaby ikonografia. Wydaje się, że na podstawie powyższych przesłanek można uznać za historycznie prawdopodobne, by Paweł i jego adresaci w Koryncie wiedzieli o rzymskiej procesji triumfalnej, trudno jednak powiedzieć, na ile znali szczegóły ceremonii. $^{37}$

Prawdopodobieństwo na podstawie tła (świadectwo wewnętrzne): Paweł w swoich listach szeroko korzysta ze słownictwa związanego ze sferą militarną i - co bardzo istotne - czyni to właśnie w sposób metaforyczny, w odniesieniu do swojej służby apostolskiej lub życia innych wyznawców

${ }^{35}$ Ibidem, s. 88-89; F. Richard, „Les images du triomphe de Claude sur la Bretagne”, [w:] Y. Burnand, Y. Le Bohec, J. Martin (red.) Claude de Lyon, empereur romain: Actes du colloque Paris - Nancy - Lyon, Novembre 1992, Paris 1998, s. 355-371.

${ }^{36}$ Heilig, Paul's Triumph (cyt. w przyp. 7), s. 131-132. Należy wspomnieć jeszcze o innych korynckich zabytkach - łuku z rzeźbami rydwanów, o których wspomina Pauzaniasz, Graeciae descriptio I 3,2 oraz tzw. Fasadzie Jeńców z motywami triumfu rzymskiego i przedstawieniami pokonanych wrogów. W odniesieniu do drugiego zabytku C. Heilig zwraca uwagę, że jego datowanie jest sporne i istnieje pewne prawdopodobieństwo, by oglądał go sam Paweł i członkowie korynckiej wspólnoty: zob. Heilig, Paul's Triumph (cyt. w przyp. 7), s. 127, przyp. 51. Należy jednak przyznać, że w literaturze zwykle przyjmuje się znacznie późniejsze datowanie Fasady Jeńców, tj. od okresu panowania Nerona aż po dynastię Sewerów, zob. A. Ajootian, „Simulacra civitatum at Roman Corinth”, Hesperia: The fournal of the American School of Classical Studies at Athens 83 (2014), s. 316, przyp. 6.

${ }^{37} \mathrm{~W}$ wielu opracowaniach, które zakładają, że Paweł wiedział o ceremonii triumfu rzymskiego, z góry przyjmuje się także, że posiadał on wiedzę na temat dokładnego jej przebiegu (np. o egzekucji jeńców czy kadzidłach). W tym miejscu należy wyraźnie przyznać, że takie twierdzenie jest bezpodstawne. Ponieważ nie oglądał on triumfu osobiście i musiałby bazować na informacjach z drugiej ręki, jego wiedza z pewnością byłaby niepełna - nam zaś brakuje danych, by stwierdzić, jaki był jej zakres. 
Chrystusa. ${ }^{38}$ Sam obraz triumfu w 2 Kor 2:14 nie byłby jedynym odwołaniem do tego zjawiska w Corpus Paulinum - często przyjmuje się, że występuje on również w Kol 2:15, gdzie autor używa tego samego czasownika $\theta \rho ı \mu \beta \varepsilon v \omega_{\omega}{ }^{39} \mathrm{Z}$ drugiej strony dyskusyjne autorstwo tego listu sprawia, że potraktowanie go jako świadectwa wewnętrznego nie jest jednoznaczne, innych przykładów brak zaś w listach Pawła.

Pozostaje jeszcze pytanie, czy taka metafora rzeczywiście wypływałaby naturalnie z najbliższego kontekstu literackiego. Jak ustaliliśmy powyżej,

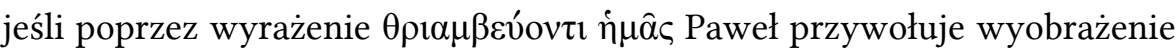
triumfu rzymskiego, sam nie pełni w nim funkcji zbyt pozytywnej - najprawdopodobniej przyjmuje rolę upokorzonego jeńca wleczonego w pochodzie. Czy jest więc możliwe, by taki obraz był częścią dziękczynienia (Tộ $\delta \grave{\varepsilon}$

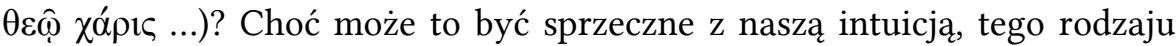
paradoksy są dość typowe dla apostoła Pawła i nie możemy wykluczyć ich obecności również w naszym tekście. ${ }^{40}$ Obraz triumfu dobrze wpisuje się też w kontekst tej części listu. Przed wyprowadzeniem omawianej metafory Paweł porusza bowiem temat swojego cierpienia (1:3-11) oraz podróży misyjnej (1:12-2:13). Obraz więźnia wleczonego w pochodzie, choć bardzo oryginalny, dobrze spełniałby rolę podsumowania, ponieważ zawiera w sobie aspekt zarówno cierpienia, jak i ruchu. ${ }^{41}$

Potencjat wyjaśniajacy: Najlepszym argumentem za tym, że hipoteza triumfu rzymskiego dobrze wyjaśnia sposób sformułowania naszej metafory z 2:14, jest to, że Paweł używa w niej właśnie czasownika $\theta \rho \iota \mu \beta \varepsilon v ́ \omega$. Jest to czasownik dość specyficzny. Do końca II w. pojawia się w literaturze greckiej 104 razy (16 razy przed powstaniem 2 Kor, m.in. u Polibiusza, Dio-

${ }^{38}$ R. A. Hobus, St Paul's Use of Military Terms in his Epistles, thes. Bachelor of Divinity, Saint Louis 1949, s. 19-78.

${ }^{39}$ P. T. O’Brien, Colossians - Philemon $[=$ Word Biblical Commentary 44], Waco 1982, s. 128 129; J. D. G. Dunn, The Epistles to the Colossians and to Philemon [The New International Greek Testament Commentary Series], Grand Rapids - Michigan 1996, s. 168-169; B. ADAмczEwsкi, List do Filemona. List do Kolosan [= Nowy Komentarz Biblijny 12], Częstochowa 2006, s. 272-273.

${ }^{40} 1$ Kor 3:18; 2 Kor 6:10, 7:4, 12:10. Podobnie zauważa Williamson, „Led in triumph” (cyt. w przyp. 24), s. 325-326.

${ }^{41}$ Kwestia kontekstu retorycznego 2:14 zostanie omówiona szerzej podczas interpretacji tekstu na poziomie metaforycznym. 
dora Sycylijskiego czy Strabona), przeważnie w literaturze historycznej podejmującej temat dziejów Rzymu. ${ }^{42}$ Wyniki badań, jakie opublikował najpierw Cilliers Breytenbach, a po nim Christoph Heilig, wykazały, że wszystkie przypadki użycia tego leksemu w korpusie TLG nawiązują właśnie do rzymskiej ceremonii triumfu, co więcej, wszystkie poza kilkoma wyjątkami odnoszą się do rzeczywistego wydarzenia. ${ }^{43}$ Wobec tych ustaleń drastycznie maleje prawdopodobieństwo, że w naszym tekście należy go odczytać w odwołaniu do jakiegoś innego tła.

Na podstawie powyższych obserwacji możemy stwierdzić, że hipoteza triumfu rzymskiego spełnia wszystkie kryteria, które przyjęliśmy, i tym samym musi zostać uznana za prawdopodobną. $W$ tym miejscu możemy więc przejść do dalszej interpretacji tekstu.

\section{b) Interpretacja tekstu na poziomie metaforycznym}

Najlepsze efekty przyniesie zinterpretowanie znaczenia naszej metafory na podstawie kontekstu retorycznego. Opierając się w tej kwestii na spojrzeniu Bena Witheringtona III, możemy uznać, że 2:14-16 stanowi zwieńczenie narratio (1:8-2:16), w której na pierwszy plan wysuwają się dwa tematy: kwestia cierpienia (1:8-11) oraz zmian w kierunkach podróży misyjnej (1:12-2:13). ${ }^{44}$ Ta druga kwestia jest tu szczególnie ważna $z$ kilku powodów - Paweł poświęca jej najwięcej miejsca, bezpośrednio poprzedza ona

${ }^{42}$ HeLis, Paul's Triumph (cyt. w przyp. 7), s. 37-51.

${ }^{43}$ Breytenbach, „Paul's proclamation” (cyt. w przyp. 26), s. 260; Heilig, Paul's Triumph (cyt. w przyp. 7), s. 32-73.

${ }^{44}$ B. Witherington III, Conflict and Community in Corinth. A Socio-Rhetorical Commentary on 1 and 2 Corinthians, Grand Rapids 1995 [e-book], loc. 811.3/1169; IDEM, New Testament Rhetoric. An Introduction Guide to the Art of Persuasion in and of the New Testament, Eugene 2009, s. 129-130. Inne propozycje ujęcia dispositio 2 Kor przedstawili: G. A. Kennedy, New Testament Interpretation through Rhetorical Criticism, Chapel Hill 1984, s. 87-91; K. YAMADA, „Epistolary theoretical and rhetorical analyses of 2 Cor. 1-9", Annual of the fapanese Biblical Institute 24 (1998), s. 100-116; F. J. Long, Ancient Rhetoric and Paul's Apology. The Compositional Unity of 2 Corinthians, Cambridge - New York 2004, s. 143-198; M. KowalsKI, „Sługa słowa i chluba Koryntu. Analiza literacko-retoryczna argumentacji Pawła w 2 Kor 1-7”, The Biblical Annals 3 (2015), s. 324-337. 
nasz fragment, a ze względu na wydźwięk polemiczny wydaje się punktem zapalnym w relacji między apostołem a Koryntianami. Paweł, który nie przybył do miasta mimo wcześniejszych planów, broni się przed zarzutem o lekkomyślne postępowanie (1:12-24). Jednak zaraz potem, opisując nagle przerwaną misję w Troadzie, niejako dolewa oliwy do dopiero co przygaszonego ognia (2:12-13). W tym właśnie miejscu narracja zostaje nagle przerwana przez nasz tekst. Wydaje się, że Paweł mógł zdać sobie wówczas sprawę, że w oczach odbiorców zaprzecza sam sobie, urywa więc szybko narrację i zamyka ją zaskakującym dziękczynieniem. Najpewniej miałoby ono stanowić kontrę wobec obrazu cierpiącego, chaotycznego apostoławłóczęgi, który Koryntianie wyciągali z działalności Pawła, a teraz mogliby wyciągnąć z jego własnych słów. W tym miejscu apostoł składa więc dziękczynienie, przedstawiając wyobraźni słuchaczy obraz rzymskiej procesji triumfalnej, w której jest on wiedziony przez Boga jako jeniec. Jaki jest więc wydźwięk tego obrazu?

Wyobrażenie procesji, jak i sam czasownik $\theta \rho \iota \alpha \mu \beta \varepsilon v ́ \omega$, związane są bezpośrednio z ruchem. ${ }^{45}$ Stąd możemy sądzić, że w ten sposób Paweł odnosi się przede wszystkim do głównego tematu narratio (zmian w podróżach misyjnych) i za pomocą barwnej metafory zbija zarzuty swoich przeciwników. $\mathrm{W}$ ten sposób pokazuje bowiem, że w służbie apostolskiej spełnia jedynie rolę wykonawcy cudzej woli - jako jeniec, nie on odpowiada za trasę pocho$\mathrm{du}$, ale wiedziony jest przez triumfatora, samego Boga. W związku z tym Koryntianie nie mogą mieć do niego pretensji za zmiany na trasie podróży.

Znaczenie czasownika $\theta \rho \iota \mu \beta \varepsilon v ́ \omega$ obejmuje także pokazywanie widzom tego, co wiedzione jest w pochodzie. ${ }^{46}$ Obraz niewolnika wleczonego w procesji mógłby więc wyrażać to, że nawet jeśli służba Pawła pełna jest cierpienia i niepowodzeń, to również te sytuacje przyczyniają się ostatecznie do szerzenia ewangelii. Za tym punktem widzenia przemawiają dwie zasadnicze przesłanki z najbliższego kontekstu. Po pierwsze, w wersecie 2:12 Paweł wspomina o misji w Troadzie, którą ostatecznie musiał przerwać, ale mimo to była ona w jakiś sposób udana. ${ }^{47}$ Po drugie, podobnego wydźwięku może-

\footnotetext{
${ }^{45}$ HeILIG, Paul's Triumph (cyt. w przyp. 7), s. 247-248.

${ }^{46}$ Ibidem, s. 101.

${ }^{47}$ Uważa się, że obecny w 2 Kor 2:12 motyw otwartej bramy wiąże się właśnie z powodze-
} 
my dopatrywać się w dalszej części obrazu z 2:14 - „i w każdym miejscu roznosi przez nas woń Jego poznania" ${ }^{48}$ - choć metafora ta może posiadać wiele kontekstów na poziomie literalnym, zasadniczo interpretowana jest w odniesieniu do służby ewangelizacyjnej Pawła. ${ }^{49}$

Scott Hafemann analizując przebieg triumfu rzymskiego zwraca uwagę głównie na egzekucję jeńców prowadzonych w pochodzie i odczytuje metaforę przede wszystkim pod kątem cierpienia Pawła. ${ }^{50} \mathrm{Z}$ naszych poprzednich rozważań wynika jednak, że nie powinniśmy nadawać zbyt dużego znaczenia temu aspektowi. Po pierwsze, prowadzenie na śmierć nie mieści się wprost $\mathrm{w}$ polu znaczeniowym czasownika $\theta \rho ı \mu \mu \beta \varepsilon v ́ \omega$; po drugie, nie możemy mieć pewności, że Paweł chciał zwrócić uwagę właśnie na ten element procesji, ani że w ogóle o nim wiedział; po trzecie, kwestia cierpień, choć znajduje się w narratio, nie została w nim zbytnio rozwinięta i nie jest podejmowana w sposób polemiczny. Mimo to, temat cierpienia jest obecny w narratio, powraca także w innych miejscach listu i nie można wykluczyć, że Paweł chciałby niejako dodatkowo zwrócić nań uwagę. Szerszy obraz procesji triumfalnej rzeczywiście może przywodzić na myśl los jeńców, jednak nie ma powodu, by ograniczać się wówczas tylko do kwestii egzekucji. Czasownik $\theta \rho ı \mu \beta \varepsilon v ́ \omega \mathrm{w}$ pierwszej kolejności wyraża bowiem ich prowadzenie i ukazywanie publiczności, ${ }^{51}$ to zaś bardziej wskazywałoby na dozna-

niem w ewangelizacji, w podobnym znaczeniu pojawia się on również w 1 Kor 16:8-9, zob. R. P. Martin, 2 Corinthians [ = Word Bibilical Commentary 40], Waco 1986, s. 41-42; D. E. GARLAND, 1 Corinthians [Baker Exegetical Commentary on the New Testament], Grand Rapids 2003 [e-book], loc. 1732.5/2202.

${ }^{48}$ Przekład własny.

49 A. PACIOREK, Drugi List do Koryntian [= Nowy Komentarz Biblijny 8], Częstochowa 2017, s. 173; D. A. Kureк-Сномүсz, „Spreading the sweet scent of the Gospel as the cult of the Wise. Sapiential background of Paul's olfactory metaphor in 2 Cor 2:14-16", [w:] C. A. EBERHART (red.), Ritual and Metaphor: Sacrifice in the Bible [= Society of Biblical Literature Resources for Biblical Study 68], Atlanta 2011, s. 115-134; EADEM, „The scent of (mediated) revelation? Some remarks on the use of phaneroo with a particular attention to 2 Cor 2,14", [w:] R. BIERINGER, M. M. S. IBita, D. A. KureK-С homycz, T. A. Vollmer (red.), Theologizing in the Corinthian Conflict: Studies in Exegesis and Theology of 2 Corinthians [= Biblical Tools and Studies 16], Leuven 2013, s. 69-108.

${ }^{50}$ Hafemann, Suffering and the Spirit (cyt. w przyp. 25), s. 16-34.

${ }^{51}$ Helis, Paul's Triumph (cyt. w przyp. 7), s. 101. 
waną przez nich hańbę. ${ }^{52}$ Hańba ta paradoksalnie przyczynia się do chwały triumfatora i w ten sposób Paweł mógłby zwracać uwagę na tego rodzaju podwójny charakter swojej służby - on, cierpiąc prześladowania, doznając niepowodzeń i pogardy, jednocześnie przynosi chwałę Bogu. ${ }^{53}$ Taki właśnie sposób myślenia możemy widzieć np. w licznych wzmiankach, gdzie Paweł mówi o sobie jako o niewolniku Chrystusa. ${ }^{54}$ Także w toku samej korespondencji korynckiej, zamiast zaszczytów, wymienia całe katalogi cierpień i niepowodzenn. ${ }^{55}$ Wydaje się, że rzeczy, które w ówczesnej kulturze byłyby powodem do wstydu, dla Pawła są wręcz oznaką jego służby apostolskiej. ${ }^{56}$

\subsection{Procesja religijna}

W całej historii badań nad tym tekstem widoczny jest nurt badaczy, według których Paweł w 2 Kor 2:14 nawiązywałby do procesji stricte religijnej, najpewniej bakchicznej. ${ }^{57}$ Jak wyraził to Harold W. Attridge:

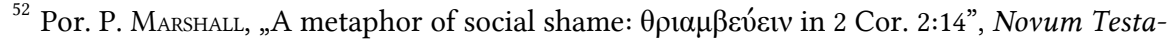

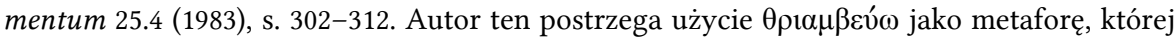
głównym wydźwiękiem jest hańba. Łacińskie analogie, na których bazuje, nie są jednak miarodajne, zob. Heilig, Paul's Triumph (cyt. w przyp. 7), s. 112-115.

${ }^{53} \mathrm{Z}$ innych części korespondencji (np. 1 Kor 4:10-13) możemy się domyślać, że Pawłowi zarzucano słabość, a jego cierpienia budziły kontrowersje wśród Koryntian. Wówczas i taki aspekt metafory mógłby posiadać wydźwięk apologetyczny.

${ }^{54} \mathrm{Rz}$ 1:1; Gal 1:10; Tt 1:1; zob. też 2 Kor 11:23.

${ }^{55} 1$ Kor 4:9-13; 2 Kor 4:8-9; 6:4-10; 11:23-33. Na szczególną uwagę zasługuje pierwszy passus, który Scott Hafemann uznał wręcz za „dokładną” paralelę do 2 Kor 2:14, zob. HafemanN, Suffering and the Spirit (cyt. w przyp. 25), s. 52-59. Jednak ponieważ w centrum metafory triumfu nie znajduje się raczej kwestia śmierci, nie możemy w pełni przychylić się do tego twierdzenia. Mimo to, nie sposób zlekceważyć podobieństw między tymi dwoma tekstami obydwa wydają się wyrażać ten sam sposób myślenia Pawła o sobie samym jako cierpiącym wysłanniku Chrystusa.

${ }^{56}$ Marshall, „A metaphor of social shame” (cyt. w przyp. 52), s. 315; T. B. SAvage, Power Through Weakness. Paul's Understanding of the Christian Ministry in 2 Corinthians [= Society for the New Testament Studies Monograph Series 86], Cambridge 2004, s. 145-163.

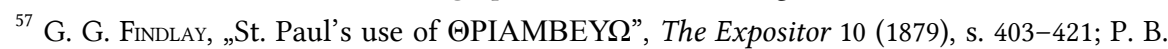
DufF, „Metaphor, motif, and meaning. The rhetorical strategy behind the image «led in triumph» in 2 Corinthians 2:14", Catholic Biblical Quaterly 53 (1991), s. 79-92; H. W. Attridge,
} 
On the level of the image, therefore, Paul portrays himself either as a devotee of the deity, like one of the women in the Isis procession described byApuleius, or like a satyr in the ritualized 'triumph' of Dionysus. It is in thatsense, rather than in the sense of a captive being led to the slaughter, that he is being 'led in triumph'.

Jak wykazuje Paul B. Duff, obraz triumfu nie ogranicza się tylko do rzymskiej procesji militarnej - w metaforyczny sposób mogły być tak przedstawiane również procesje ku czci bóstw. Świadczyć o tym mają zarówno przesłanki filologiczne, gdyż w tytulaturze wielu bogów znajduje się słownictwo związane $\mathrm{z}$ triumfem i zwycięstwem militarnym, a także przedstawienia ikonograficzne, które niejednokrotnie wyobrażają pochód triumfalny z udziałem bogów. ${ }^{59}$ Interpretatorzy 2 Kor 2:14 wykorzystują jednak to powiązanie triumfu i procesji w różny sposób. Sam Paul. B. Duff sądzi, że Paweł zamierzał ukazać metaforę niejednoznaczną, dopuszczającą obydwa te obrazy, Harold W. Attridge uważa natomiast, że Paweł przedstawił wyłącznie obraz procesji religijnej, nie mając w ogóle na myśli triumfu rzymskiego ${ }^{60}$ Choć hipoteza ta stoi w oczywistej sprzeczności ze zreferowanymi wcześniej ustaleniami na temat zastosowania czasownika $\theta \rho ı \mu \mu \beta \varepsilon v ́ \omega$ w literaturze starożytnej, warto przyjrzeć się jej szczegółom.

\section{a) Interpretacja tekstu na poziomie literalnym}

Prawdopodobieństwo na podstawie tła (świadectwo zewnętrzne): Paweł z pewnością mógł posiadać jakąś wiedzę na temat kultu Dionizosa, gdyż był on szeroko rozpowszechniony na obszarze jego działalności. Poświadczony jest $\mathrm{w}$ miastach, w których apostoł przebywał, np. w Tarsie, Filippi, Tesa-

„Making scents of Paul. The background and sense of 2Cor 2: 14-17”, [w:] J. T. Fitzgerald, T. H. Olbricht, L. M. Whiтe (red.), Early Christianity and Classical Culture. Comparative Studies in Honor of Abraham f. Malherbe [= Supplements to Novum Testamentum 110], Leiden Boston 2003, s. 71-88.

${ }^{58}$ Attridge, „Making scents of Paul” (cyt. w przyp. 57), s. 83.

${ }^{59}$ DufF, „Metaphor, motif, and meaning” (cyt. w przyp. 57), s. 83-86.

${ }^{60}$ Ibidem, s. 91-92; ATtRIDGE, „Making scents of Paul” (cyt. w przyp. 57), s. 83. 
lonice, Atenach, Efezie czy Troadzie. ${ }^{61}$ Prawdopodobieństwo to rośnie jeszcze bardziej, jeśli weźmiemy pod uwagę fakt, że procesje były nieodłącznym elementem bardzo wielu świąt $\mathrm{w}$ świecie antycznym, daleko wykraczającym poza kult samego Dionizosa. ${ }^{62}$ Skoro jednak mówimy o kultach tak powszechnych i obejmujących bardzo wiele różnych obrzędów, pojawia się pytanie, na ile prawdopodobne jest, by Paweł zwrócił szczególną uwagę akurat na ceremonię procesji. Otóż istnieje możliwość, by był on świadkiem takiego wydarzenia w samym Koryncie - jeśli przybył do miasta pomiędzy styczniem a marcem 50 r., mógłby oglądać procesję podczas Antesteriów, które odbywały się na przełomie lutego i marca. ${ }^{63}$ Jednak to głównie powszechność tego typu praktyk wpływa na mocne świadectwo zewnętrzne tej hipotezy.

Prawdopodobieństwo na podstawie tła (świadectwo wewnętrzne): Jak wskazuje George G. Findlay, Paweł kilkukrotnie w swoich pismach posługuje się obrazem greckiego agonu, a być może także przedstawień teatralnych. ${ }^{64}$ Trudno jednak znaleźć inne miejsce w pismach Pawła, gdzie apostoł opisywałby działanie Boga poprzez bezpośrednią analogię do pogańskich praktyk kultowych. Jeśli w ogóle się do nich odwołuje, czyni to poprzez antytezę, przeciwstawiając sobie zachowanie pogan i chrześcijan. ${ }^{65}$ Co więcej, jeszcze w 1 Kor 8:1-13 i 10:14-33, zwracając się do tego samego audytorium, odradza spożywania mięsa składanego na ofiarę bóstwom pogańskim, gdyż mogłoby to wyglądać na udział w bałwochwalstwie, sam zaś kult osądza surowo jako kult demonów nie do pogodzenia z oddawaniem czci Bogu. Na tej podstawie możemy sądzić, że nawiązanie do pogańskiej ceremonii religijnej w naszym tekście nie byłoby tym, czego moglibyśmy się spodzie-

${ }^{61}$ Heilig, Paul's Triumph (cyt. w przyp. 7), s. 141, przyp. 135; E. J. Schnabel, Early Christian Mission, t. 2: Paul \& the Early Church, Downers Grove 2004, s. 1057, 1153, 1164, 117.1-76, 1210, 1249.

${ }^{62}$ S. R. F. Price, A. Merkt, „Procession”, [w:] H. CanciK, H. Schneider (red.), Brill's New Pauly. Encyclopaedia of the Ancient World. Antiquity, Leiden - Boston 2007, s. 905-907.

${ }^{63}$ Heilig, Paul's Triumph (cyt. w przyp. 7), s. 142.

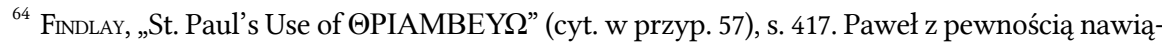
zuje do zawodów sportowych w 1 Kor 9:24-27 i Flp 3:11-14, jednakże odwołania do teatru w 1 Kor 4:9; 7:31 i 2 Kor 4:10,11 na które powołuje się Findlay, są już dużo mniej oczywiste.

${ }^{65}$ Przykładem może być 1 Tes 4:1-9; 5:5-8, gdzie niektórzy badacze dopatrują się odwołania do kultów misteryjnych związanych z Kabirami oraz Dionizosem, zob. np. R. RIESNER, Paul's Early Period: Chronology, Mission Strategy, Theology, Grand Rapids 1997, s. 374-375. 
wać po apostole Pawle. Niestety wymienieni wyżej badacze nie odnoszą się do tego problemu.

Mimo to, należy jeszcze przeanalizować kwestię najbliższego kontekstu literackiego. Badacze opowiadający się za tą opcją nie poświęcają uwagi wcześniejszej partii tekstu 2 Kor i temu, jak obraz procesji miałby z niej wypływać. ${ }^{66}$ Jedynie Paul B. Duff wyraźnie wskazuje powód tego postępowania - czyni tak dlatego, że traktuje 2 Kor 2:14-6:13; 7:2-4 jako osobny fragment, próbuje więc odczytać nasz tekst raczej pod kątem dalszej treści listu. ${ }^{67}$ Pod uwagę bierze przede wszystkim dwie kwestie będące przypuszczalnie przedmiotem sporu między Pawłem a Koryntianami, tj. zarzut o oszustwo oraz cierpienie apostoła i w tym kontekście odczytuje metaforę

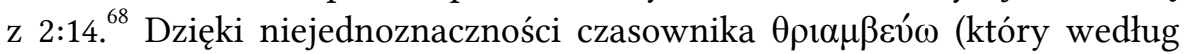
autora może odnosić się zarówno do procesji militarnej, jak i stricte religij$\left.n \mathrm{j}^{69}\right)$ metafora miałaby spełniać rolę insinuatio - Paweł wychodziłby od negatywnego obrazu triumfu rzymskiego, który zgadza się z wizją jego przeciwników, by w dalszej części listu przedefiniować ten obraz, pokazując, że tak naprawdę jest członkiem innej procesji, religijnej. ${ }^{70}$ Duff na

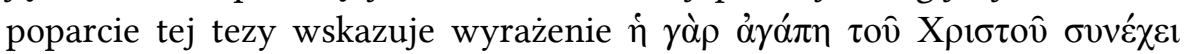
$\dot{\eta} \mu \hat{\alpha} \varsigma^{71}$ (5:14); odczytuje użyty tu czasownik $\sigma v v \varepsilon ́ \chi \omega$ jako „brać w niewolę”,

${ }^{66}$ Gdybyśmy jednak zrobili inaczej i wzięli pod uwagę tekst poprzedzający 2:14, okaże się, że obraz takiej procesji mógłby wypływać z treści narratio $\mathrm{w}$ sposób podobny do obrazu triumfu, tj. jako podsumowanie kwestii zmian w podróżach misyjnych. Metafora, w której Paweł jest częścią procesji bakchicznej, podobnie pokazywałaby Koryntianom, że apostoł w swoich podróżach nie postępuje według własnej woli, ale woli Bożej, stąd nie powinno się go krytykować.

${ }^{67}$ Duff, „Metaphor, motif, and meaning” (cyt. w przyp. 57), s. 80. Jest to rozsądne posunięcie, gdyż 2:14 traktowany jako początek fragmentu nadal mógłby spełniać funkcję podobną do narratio, tj. wprowadzać kwestie, które będą rozwinięte w głównej części listu. P. B. Duff uznaje ten werset za prooemium, zob. ibidem, s. 91.

${ }^{68}$ Ibidem, s. 80-82. Wbrew temu, w dalszej części pracy pomija kwestię oszustwa i analizuje 2:14 tylko pod kątem cierpienia.

${ }^{69}$ Ibidem, s. 83.

${ }^{70}$ Ibidem, s. 91-92.

${ }^{71}$ Werset ten w każdym niemal przekładzie tłumaczony jest inaczej z powodu niejedno-

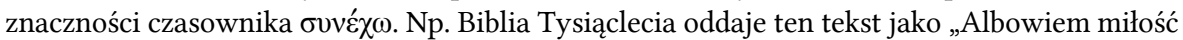
Chrystusa przynagla nas (...)”, Biblia Warszawska zaś „Bo miłość Chrystusowa ogarnia nas”. 
co byłoby aluzją do roli jeńca w triumfie. ${ }^{72}$ Całe zaś zdanie miałoby być właśnie przedefiniowaniem negatywnego wydźwięku triumfu (2:14) w następujący sposób:

Although Paul might look like he is being 'led in triumph,' a victim of defeat, the object of the vengeance of God, he is in fact a captive of the 'love of Christ' ${ }^{73}$

Dalej wymienia liczne miejsca z późniejszej treści 2 Kor, w których Paweł, robiąc aluzje do poprzedniej metafory, miałby mówić o sobie pozytywnie jako o uczestniku procesji religijnej: $4: 7 ; 4: 10 ; 6: 13 ; 7: 2 .^{74}$

Niestety ta ciekawa interpretacja nie jest wystarczająco uargumentowana i w rzeczywistości napotyka na wiele problemów. Autor bowiem dokonuje powiązania między 2:14 a 5:14 w sposób dość arbitralny, ${ }^{75}$ podobnie czyni też w przypadku przypuszczalnych nawiązań do procesji religijnej, przedstawiając co najwyżej szczątkowe przesłanki. ${ }^{76}$ Sama koncepcja,

${ }^{72}$ Ibidem, s. 86-87.

${ }^{73}$ Ibidem, s. 87.

${ }^{74}$ Ibidem, s. 87-91.

${ }^{75}$ Ibidem, s. 86-87 cytuje jedno źródło starożytne, w którym ovvé $\chi \omega$ może być rozumiane jako „brać w niewolę” (Lukian, Toxaris 3) i z góry przyjmuje takie znaczenie również w 5:14. Następnie odnosi się do Owidiusza, Amores 1 2,27-30, który przyrównuje miłość do triumfu i za tym przyjmuje, że w 5:14 występuje podobne połączenie. Samo zaś twierdzenie, że 5:14 jest reinterpretacją 2:14 pozostawia bez żadnego dowodu egzegetycznego, opierając się tylko na założonym powyżej podobieństwie motywów. Zob. też krytykę ze strony HeIlig, Paul's Triumph (cyt. w przyp. 7), s. 201.

${ }^{76}$ DuFf, „Metaphor, motif, and meaning” (cyt. w przyp. 57), s. 89, za najlepszy przykład odnie-

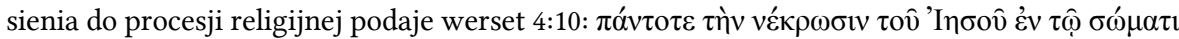
$\pi \varepsilon \rho \iota \varphi \varepsilon ́ \rho o v \tau \varepsilon \varsigma(. .$.$) („Nosimy nieustannie w ciele naszym konanie Jezusa [...]”). Autor słusznie$ zauważa, że czasownik $\pi \varepsilon \rho \iota \varphi \varepsilon ́ \rho \omega$ może być stosowany w odniesieniu do takich procesji, jednak bez dowodu przyjmuje, że tak jest również w tym przypadku. Równie dobrze werset ten mógłby zawierać jedynie obraz triumfu poprzez paralelę z 2:14. Ibidem, s. 88, podaje inny przy-

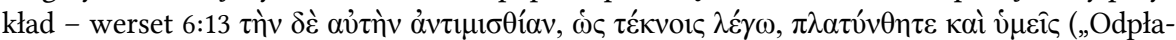
cając się nam w ten sposób, otwórzcie się i wy: jak do swoich dzieci mówię.”)”. Tu odniesieniem do procesji religijnej miałby być sam czasownik $\pi \lambda \alpha \tau u ́ v \theta \eta \tau \varepsilon$ (otwórzcie się, rozszerzcie się). Jako jedyny dowód autor przytacza odnośniki do tekstów, które wspominają o osobie krzykiem torującej drogę przed procesją, nie zastanawia się natomiast nad innym zastosowaniem ww. czasownika, ani nad kontekstem wersetu. Tego rodzaju argumentacja jest dobrą ilu- 
by Paweł posłużył się swego rodzaju podwójną przenośnią, wydaje się dość karkołomna, taki zabieg byłby bardzo trudny do wychwycenia dla słuchaczy.

Harold W. Attridge w znacznym stopniu odchodzi od argumentacji Duffa. Właściwie pomija on kontekst retoryczny, jak również dalszą treść 2 Kor i przede wszystkim stara się wykazać, że jeśli założymy w 2:14 obraz procesji religijnej, wówczas również pozostałe obrazy w całej perykopie dają się dobrze odczytać według tego klucza. Łączyłby on bowiem motyw procesji z motywem zapachu i objawienia. Na potwierdzenie przytacza źródła starożytne, według których podczas takich procesji używano wonności, a sam zapach czasami traktowano jako zwiastun obecności bóstwa. ${ }^{77}$ Możliwe więc, że Paweł w 2:14-17 odwołuje się do różnych aspektów tego samego, nadrzędnego obrazu, którym jest procesja religijna. ${ }^{78}$ Attridge podsumowuje swoje spojrzenie następująco:

Paul's imagery in 2Cor 2:14-17 can be construed as a consistent development of the imagery of sacred unguents used in religious 'triumphs' in which devotees made known the presence of a deity and also their relationship to the potent power celebrating the triumph. ${ }^{79}$

Trzeba przyznać, że argumenty Harolda W. Attridge’a wydają się przekonujące. To, że różnego rodzaju wrażenia zapachowe towarzyszyły procesjom religijnym, jest dostatecznie poświadczone w źródłach starożytnych, podobnie jest również w przypadku kultowego wymiaru zapachu. Pozostałe metafory rzeczywiście dobrze wpasowują się w obraz procesji. Wszystko zależy więc od tego, czy słuszne jest początkowe założenie, że Paweł użył czasownika $\theta \rho ı \mu \mu \beta \varepsilon v \omega$ właśnie w odniesieniu do procesji religijnej. To pytanie wiedzie nas wprost do rozważenia kwestii potencjału wyjaśniającego.

stracją metodologii, w której bardzo wiele uwagi poświęcono kwestii potencjału wyjaśniającego, niedostatecznie natomiast oceniono prawdopodobieństwo na podstawie tła.

${ }^{77}$ Attridge, „Making scents of Paul” (cyt. w przyp. 57), s. 81-82.

${ }^{78}$ Autor idzie jeszcze dalej, wskazując, że istnieje możliwość, by Paweł ukazywał siebie jako naczynie $\mathrm{z}$ wonnym olejkiem niesione $\mathrm{w}$ pochodzie, ponieważ $\mathrm{w}$ 4:6-7 porównuje się do glinianej lampy skrywającej blask poznania Boga, zob. ibidem, s. 83 .

${ }^{79}$ Ibidem, s. 88. 
Potencjał wyjaśniający: Podejście badaczy tego nurtu nie jest jednolite. George G. Findlay, pisząc pod koniec XIX w., nie znał wówczas żadnych przykła-

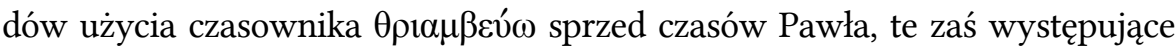
u Plutarcha, Appiana i Herodiana potraktował jako latynizm (odpowiednik triumpho), który ma rację bytu tylko w literaturze historycznej. ${ }^{80}$ Uznał więc, że Paweł musiał używać tego słowa w innym - rdzennie greckim - znaczeniu, robiąc co najwyżej aluzję do jego łacińskiego podłoża. Ponieważ nie miał do dyspozycji odpowiednich tekstów źródłowych, oparł swoje ustalenia na etymologii. Zauważył, że czasownik $\theta \rho ı \mu \beta \varepsilon v ́ \omega$ wywodzi się od rzeczownika $\theta \rho i ́-$ $\alpha \mu \beta$ oc oznaczającego pieśń na cześć Dionizosa, a co za tym idzie, także procesję

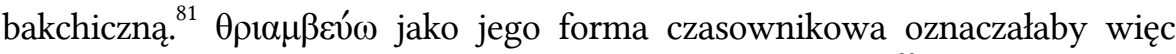
m.in. „to lead in festal or choral (dithyrambic) procession”. ${ }^{82}$ Paweł czerpałby więc to słowo wprost ze słownictwa kultowego związanego z Dionizosem.

Wspomniany autor zapewne miał rację wywodząc czasownik $\theta \rho ı \mu \beta \varepsilon v ́ \omega$ od rzeczownika $\theta$ pí $\alpha \mu \beta$ oc. ${ }^{83}$ Nie ma jednak żadnych dowodów na to, by słowo $\theta$ pí $\mu \beta$ ß oznaczało nie tylko pieśń, ale także procesję, co jest zasadniczym elementem jego hipotezy. ${ }^{84}$ Wydaje się, że wobec obecnego stanu wiedzy na temat czasownika $\theta \rho \iota \alpha \mu \beta \varepsilon u ́ \omega$, możemy powiedzieć, że hipoteza

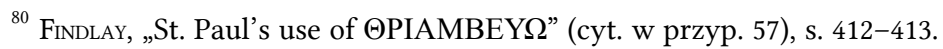

${ }^{81}$ Ibidem, s. 414-415.

${ }^{82}$ Ibidem, s. 416.

${ }^{83}$ Zob. P. Chantraine, Dictionnaire étymologique de la langue grecque. Histoire des mots, t. 2,

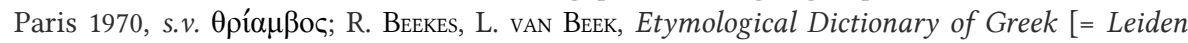

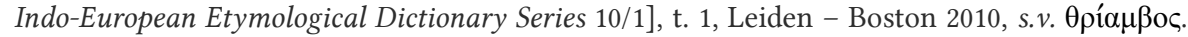
Pochodzenie $\theta \rho \imath \alpha \mu \beta \varepsilon v ́ \omega$ od $\theta \rho i ́ \alpha \mu \beta$ oc nie prowadzi jednak do dalszych wniosków Findlaya, gdyż historia obu tych słów jest najpewniej znacznie bardziej skomplikowana. Według H. S. Versnel, Triumphus. An Inquiry into the Origin, Development and Meaning of the Roman

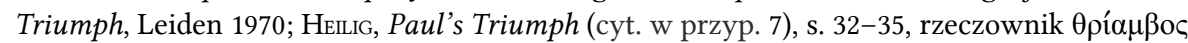
rzeczywiście pierwotnie związany był z kultem Dionizosa, jednak wcześnie dotarł do Rzymu za pośrednictwem Etrusków i zaczął coraz bardziej osadzać się w kontekście świętowania zwycięstwa militarnego, tracąc swój pierwotny kontekst. Wówczas słowo $\theta$ pía $\mu \beta$ os ponownie weszło do języka greckiego, tym razem jako odpowiednik łacińskiego triumphus (stąd posiada ono dwa, stosunkowo odległe od siebie znaczenia). Dopiero wówczas pojawił się cza-

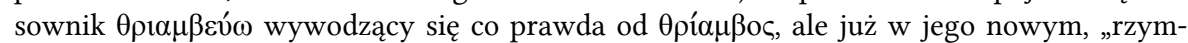
skim” znaczeniu, jako odpowiednik łacińskiego triumpho.

${ }^{84}$ HeILIG, Paul's Triumph (cyt. w przyp. 7), s. 199. Teoretycznie mogłaby tutaj zajść metonimia, jednak do utrzymania hipotezy potrzebny byłby na to konkretny dowód z literatury.
} 
Findlaya nie sprawdziła się. Znamy bowiem dużo więcej przykładów jego użycia, także sprzed czasów Pawła, i z pewnością żaden nie odnosi się do procesji bakchicznej. Bardzo mało prawdopodobne jest więc, by Paweł chciał do niej nawiązać właśnie przez czasownik $\theta \rho ı \mu \mu \beta \varepsilon v ́ \omega$ - spodziewalibyśmy się tutaj innego słownictwa.

Paul B. Duff, a za nim Harold W. Attridge, uważają natomiast, że czasownik $\theta \rho ı \mu \beta \varepsilon u ́ \omega$ zasadniczo odnosi się do triumfu rzymskiego, lecz może być stosowany szerzej w odniesieniu do innych procesji, ponieważ czasem metaforycznie postrzegano je $\mathrm{w}$ kategoriach triumfu. Hipoteza ta opiera się przede wszystkim na obserwacji, że szerokie słownictwo związane ze zwycięstwem militarnym i triumfem odnoszone było do szeregu bóstw greckorzymskich i egipskich. ${ }^{85}$ Niektóre wersje mitu o Dionizosie opowiadają o jego podboju Indii oraz następującym po tym triumfie, ${ }^{86}$ samo zaś słowo $\theta$ pía $\mu \beta$ oc pojawia się także jako przydomek lub pieśń skierowana do tego bóstwa. ${ }^{87}$ W tytulaturze Izydy znalazły się takie określenia jak invicta, victrix i triumphalis, zaś opis procesji ku czci bogini autorstwa Apulejusza zawiera wyrażenie triumphalis turbula. ${ }^{88}$ Również bogowie Serapis, Anubis oraz Horus

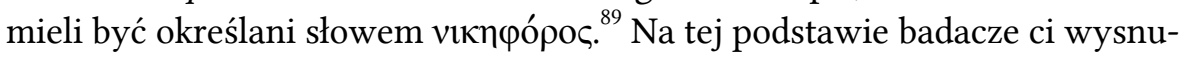
wają wniosek, że niektóre procesje objawiające obecność „Zwycięskich” bogów mogły być opisywane metaforycznie jako triumf rzymski i do takiej właśnie ceremonii nawiązywałby Paweł poprzez czasownik $\theta \rho ı \mu \mu \beta \varepsilon \omega_{\omega} .^{90}$

Findlay nie dostarcza go - wskazuje jedynie na podobną różnorodność znaczeniową rze-

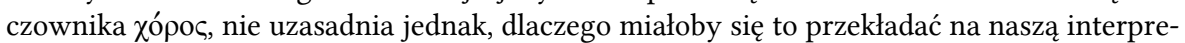

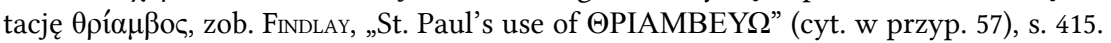

${ }^{85}$ Duff, „Metaphor, motif, and meaning” (cyt. w przyp. 57), s. 83-86; AtTridge, „Making scents of Paul" (cyt. w przyp. 57), s. 80-82.

${ }^{86}$ Diodor Sycylijski, Bibliotheca historica 4.3.1. Zwycięski powrót Dionizosa z Indii pojawia się także w sztuce plastycznej, przy czym w niektórych tego typu wyobrażeniach można dopatrywać się elementów nawiązujących do ceremonii triumfu, zob. DufF, „Metaphor, motif, and meaning" (cyt. w przyp. 57), s. 85-86.

${ }^{87}$ Atenajos, Deipnosophistae XIV 617B-F.

${ }^{88}$ Invicta - CIL VI 352,355; Apulejusz, Metamorphoses XI 7; victrix - CIL IX 3144 ,5179; XI 695; triumphalis - CIL VI 355; triumphalis turbula - Apulejusz, Metamorphoses XI 7.

${ }^{89}$ IG II 1230, 1304.

${ }^{90}$ DufF, „Metaphor, motif, and meaning” (cyt. w przyp. 57), s. 86; AтtridGE, „Making scents of Paul" (cyt. w przyp. 57), s. 83. 
Mimo że sama ilość powyższych tekstów źródłowych może robić wrażenie, nasuwa się pytanie, czy rzeczywiście stanowią one odpowiedni dowód na to, że procesje religijne mogły być postrzegane $\mathrm{w}$ kategoriach procesji triumfalnych. W żadnym z nich nie pojawia się w końcu kluczowy dla nas czasownik $\theta \rho \iota \alpha \mu \beta \varepsilon v ́ \omega$. Większość przytaczanych źródeł zawiera określenia związane ogólnie ze zwycięstwem, nie zaś z triumfem rzymskim, co nie stanowi odpowiedniej przesłanki. Z triumfem rzeczywiście łączy się wspomniany mit Dionizyjski, jednak stanowi on jedynie jego mitologiczną etiologię - niektórzy autorzy starożytni wierzyli, że znany im zwyczaj triumfu militarnego został zapoczątkowany przez Dionizosa, ${ }^{91}$ co jednak nie przedkłada się na to, że pochody dionizyjskie rozumieli w kategoriach triumfu militarnego. Również „triumfalna” tytulatura bogów nie musi przedkładać się na takie rozumienie procesji ku ich czci. Wydaje się, że jedynym argumentem mogącym wprost dowodzić omawianej hipotezy jest odniesienie do Metamorfoz Apulejusza, gdzie - zdaniem Duffa - poprzez wyrażenie triumphalis turbula opisano procesję ku czci Izydy. ${ }^{92}$ Ten argument napotyka jednak na problemy. Po pierwsze, jest to tekst łaciński z II w. n.e. Po drugie, określenie to nie opisuje samej procesji, ale sytuację przed jej rozpoczęciem - metaforycznie wyraża jedynie radosny nastrój zgromadzonych wiernych. ${ }^{93}$ Wydaje się więc, że powyższe przykłady nie stanowią wystarczającego argumentu na poparcie omawianej hipotezy. Jest mało prawdopodobne, by Paweł chciał wyrazić aluzję do procesji religijnej właśnie poprzez czasownik $\theta \rho ı \mu \beta \varepsilon v ́ \omega$ - takie jego użycie byłoby ewenementem na tle całej literatury starożytnej. ${ }^{94}$

\footnotetext{
${ }^{91}$ Zob. np. Diodor Sycylijski, Bibliotheca historica 4.5.2; Pliniusz, Naturalis historia VII 78.

${ }^{92}$ Duff, „Metaphor, motif, and meaning” (cyt. w przyp. 57), s. 84-85.

${ }^{93}$ Heilig, Paul's Triumph (cyt. w przyp. 7), s. 200.

${ }^{94}$ Czy jest jednak prawdopodobne, by Paweł zastosował ten czasownik w jakiś wyjątkowy

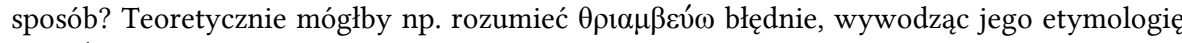
od $\theta$ pí $\alpha \beta \beta$ ○ (w znaczeniu „pieśń ku czci Dionizosa”) - tak, jak zrobił to Paul B. Duff. Byłoby to dopuszczalne, gdyby apostoł nie znał prawidłowego zastosowania czasownika w odniesieniu do procesji triumfalnej. Wcześniej przedstawiliśmy jednak przesłanki za tezą przeciwną. Poza tym nie wydaje się, by Paweł odczytując $\theta \rho ı \mu \mu \beta \varepsilon v \omega$ na podstawie dionizyjskiego $\theta$ pí $\alpha \mu \beta$ os, zrozumiał to słowo koniecznie w odniesieniu do procesji - prędzej skojarzyłby je

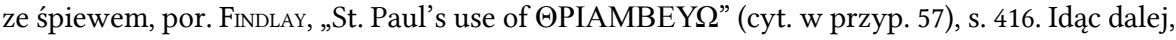


Na podstawie powyższych ustaleń możemy stwierdzić, że prawdopodobieństwo hipotezy procesji religijnej jest niewielkie. O ile prawdopodobieństwo na podstawie tła jest do pewnego stopnia dyskusyjne, hipoteza zupełnie nie spełnia kryterium potencjału wyjaśniającego i, co za tym idzie, nie może zostać przyjęta. W związku z tym, przejście do dalszej interpretacji tekstu według przyjętej metody jest niemożliwe.

\subsection{Mistyka merkawy}

Autorem hipotezy ciekawej, choć niezbyt wpływowej w badaniach, jest James M. Scott. Według jego interpretacji Paweł w 2 Kor 2:14 odnosi się do doświadczeń mistycznych związanych z nurtem tzw. mistyki merkawy. ${ }^{95}$ Teksty spisane w tej tradycji koncentrują się na ezoterycznej egzegezie starotestamentowych wizji Bożego tronu/rydwanu m.in. z Ez 1, Dn 7, czy Iz 6 oraz opisują analogiczne wizje, w których mistyk odbywa podróż poprzez siedem niebios i pałaców (Hekhalot) ku objawieniu tronu Boga (Merkavah). ${ }^{96}$ James M. Scott uznaje, że Paweł w naszym tekście odwołuje się w pierwszej kolejności do triumfu rzymskiego, przywołując obraz triumfatora na kwadrydze; wyobrażenie rydwanu odsłania jednak przed czytelnikiem drugie dno metafory - tak naprawdę chodzi tu o rydwan Boga. Paweł przy tym nawiązuje do tradycji związanej z Mojżeszem, który to według żydowskiej egzegezy Ps 68:18-19 miał mieć widzenie merkawy na górze Synaj. Stawiając się więc w roli mistyka, ukazuje Koryntianom swoją rolę pośrednika objawienia Bożego w analogii do roli Mojżesza. Jak podsumowuje autor tej hipotezy:

Paweł teoretycznie mógłby urobić nowe znaczenie czasownika. Jednak by zostać odpowiednio zrozumianym musiałby wyraźnie naprowadzić swoich odbiorców na to nowe znaczenie. Mimo to, używa go w stwierdzeniu bardzo lakonicznym i nie dookreśla w żaden sposób.

${ }^{95}$ J. M. Scott, „The triumph of God in 2 Cor 2:14. Additional evidence of Merkabah mysticism in Paul", New Testament Studies 42 (1996), s. 260-281.

${ }^{96}$ G. Scholem, Major Trends in Jewish Mysticism, New York 1974 [e-book], s. 73; A. MorrayJonES, „Transformational mysticism in the Apocalyptic-Merkabah tradition”, fournal of Jewish Studies 43 (1992), s. 2; J. Lannsma, „Mysticism”, [w:] C. A. Evans, S. E. Porter (red.), Dictionary of New Testament Background, Downers Grove 2000, s. 727. 
In 2 Cor 2.14-7.4, Paul's defence of the legitimacy of his apostolic ministry commences with an extensive comparison between his own ministry andthat of Moses. Already in 2.14, Paul uses the metaphor of a Roman triumphalprocession to conjure up an image of the throne-chariot of God which recalls a traditional reading of Ps 68(67)18-19 (cf. Eph 4.8). In this way, Paul is able to portray himself as a Moses-like figure who has an encounter with the divine Merkabah and thereby becomes a mediator of divine revelation. $^{97}$

Powyższa hipoteza stanowi pewne wyzwanie dla przyjętej przez nas metodologii. Autor widzi bowiem w tym tekście więcej płaszczyzn znaczeniowych, niż przewidzieliśmy - najpierw obraz triumfu rzymskiego, następnie kwadrygi, potem merkawy i Mojżesza, i dopiero wówczas właściwy sens metaforyczny. ${ }^{98}$ Podejście do pierwszej kwestii pokrywałoby się z naszymi wcześniejszymi ustaleniami na temat hipotezy triumfu. Jak jednak potraktować przypuszczalne nawiązanie do mistyki merkawy w naszym tekście - czy jest to jeszcze sens literalny, czy już metaforyczny? Wydaje się, że powinniśmy zbadać tę kwestię sposobem, jaki przyjęliśmy przy sensie literalnym, tj. z użyciem kryteriów Christopha Heiliga. Nadal musimy bowiem dokonać interpretacji tekstu pod kątem dodatkowego podłoża, a do tego metodologia Heiliga właśnie służy.

Prawdopodobieństwo na podstawie tła (świadectwo zewnętrzne): Trudno stwierdzić, czy w kontekście listów Pawła możemy już mówić o mistyce merkawy. Staje się ona widoczna jako w pełni wykształcony nurt duchowości żydowskiej dopiero w tzw. literaturze Hekhalot (III-VII w. n.e.), jednak pewnych elementów można dopatrywać się znacznie wcześniej, głównie w literaturze apokaliptycznej. ${ }^{99}$ Problem relacji tych dwóch nurtów jest wciąż dyskutowany i z tego powodu kwestia datowania oraz periodyzacji mistyki merkawy nie jest jednoznaczna - klasyczny model Greshoma Scholema,

\footnotetext{
${ }^{97}$ ScotT, „The triumph of God” (cyt. w przyp. 95), s. 281.

${ }^{98}$ Jak wykażemy dalej, hipoteza Jamesa M. Scotta nie wpasowuje się w nasz schemat z tego powodu, że jest niepoprawnie zbudowana i nadaje metaforze zbyt wiele znaczeń jednocześnie.

${ }^{99}$ I. GRuenwald, Apocalyptic and Merkavah Mysticism [= Ancient fudaism and Early Christianity 90], Leiden - Boston 2014, s. 3.
} 
który wyznaczał jej początek już na I w. p.n.e. jest dziś przedmiotem zarówno krytyki, jak i obrony. ${ }^{100}$ Sam fakt, by Paweł zetknął się w jakiś sposób z wczesną mistyką żydowską, nie wydaje się nieprawdopodobny, trudno natomiast powiedzieć, czy posiadałaby ona dokładnie takie cechy, jakie zakłada James M. Scott. Jeszcze trudniej określić, jaka byłaby świadomość Koryntian na ten temat. ${ }^{101}$

Prawdopodobieństwo na podstawie tta (świadectwo wewnętrzne): $\mathrm{W}$ pismach Pawła nie brakuje odniesień do doświadczeń, które moglibyśmy określić jako mistyczne, przy czym większość z nich znajduje się właśnie w obrębie 12 Kor. ${ }^{102}$ Najbardziej znaczący dla nas jest opis objawienia w 2 Kor 12:2-4:

2 Znam człowieka w Chrystusie, który przed czternastu laty - czy w ciele, nie wiem, czy poza ciałem, też nie wiem, Bóg to wie - został porwany aż do trzeciego nieba. 3 I wiem, że ten człowiek - czy w ciele, nie wiem, czy poza ciałem, <też nie wiem>, Bóg to wie -4 został uniesiony do raju i słyszał tajemne słowa, których się nie godzi człowiekowi powtarzać.

Wielu badaczy przyjmuje, że powyższy tekst zawiera elementy charakterystyczne dla mistyki merkawy. ${ }^{103}$ Jednocześnie, mimo że Paweł pisze w trze-

${ }^{100}$ Scholem, Major Trends in fewish Mysticism (cyt. w przyp. 96), s. 69; por. Gruenwald, Apocalyptic and Merkavah Mysticism (cyt. w przyp. 99); A. A. Orlov, The Enoch-Metatron Tradition, Tübingen 2005, s. 1-6; M. Himmelfarb, „Heavenly ascent and the relationship of the apocalypses and the «Hekhalot» literature", Hebrew Union College Annual 59 (1988), s. 73-100; D. J. Halperin, The Faces of the Chariot. Early Jewish Responses to Ezekiel's Visions, Tübingen 1988; P. ScHÄFER, The Origins of Jewish Mysticism, Princeton - Oxford 2009.

${ }^{101}$ Sam fakt, że Paweł pisze do wspólnoty w greckim Koryncie, na pewno nie przesądza o tym, że jej przedstawiciele nie mogliby mieć styczności z mistyką żydowską. Najpewniej była to bowiem wspólnota mieszana - znajdowali się $\mathrm{w}$ niej także wierni pochodzenia żydowskiego; zob. Witherington III, Conflict and Community in Corinth (cyt. w przyp. 44), loc. 69.0-75.5/1169.

${ }^{102}$ James B. Wallace wymienia m.in.: wizje i objawienia Pana (1 Kor 9:1; 15:8-11; 2 Kor 3:1618; 4:5-12; Gal 1:11-17), inne doświadczenia objawienia (Gal 3:1-5; 1 Kor 2:6-16; 14:26-33), doświadczenie boskiej mowy (Rz 8:9-27; 1 Kor 14; 2 Kor 13:2-5; Gal 4:6), zob. J. B. Wallace, Snatched into Paradise (2 Cor 12:1-10). Paul's Heavenly fourney in the Context of Early Christian Experience [= Beihefte zur Zeitschrift für die neutestamentliche Wissenschaft und die Kunde der älteren Kirche 179], Berlin - New York 2011, s. 169-230.

${ }^{103}$ Zob. G. G. Scholem, Jewish Gnosticism, Merkabah Mysticism, and Talmudic Tradition. Based on the Israel Goldstein Lectures, Delivered at the Jewish Theological Seminary of America, New 
ciej osobie, najpewniej opisuje własne doświadczenia mistyczne, ${ }^{104}$ można byłoby go więc uznać za mistyka tego nurtu. Jednakże James B. Wallace autor dotąd najbardziej wyczerpującej analizy Pawłowej wizji - zauważa, że motyw uniesienia do nieba jest szeroko spotykany w literaturze starożytnej, a możliwe paralele mogą sięgać nie tylko poza literaturę Hekhalot, ale w ogóle poza literaturę żydowską. ${ }^{105}$ Poszczególne elementy Pawłowego opisu wydają się współgrać $\mathrm{z}$ wieloma różnymi tradycjami, jednak całego tekstu nie można $\mathrm{w}$ pełni zaliczyć do żadnej z nich, gdyż w dużej mierze jest oryginalny. ${ }^{106}$ Odczytywanie objawienia Pawła w świetle już ukształtowanego nurtu mistyki merkawy może prowadzić do nadinterpretacji, gdy na podstawie kilku fragmentarycznych analogii do tej tradycji automatycznie przypisuje się autorowi cały „zestaw” wierzeń i praktyk z nią związanych - w tym np. widzenia rydwanu Bożego, o których przecież nie wspomina wprost. ${ }^{107}$

W omawianej hipotezie ważną rolę odgrywa nawiązanie do tradycji o Mojżeszu na podstawie Ps 68:18-19. W związku z ostatnią uwagą, warto zastanowić się, czy Paweł znał tę tradycję. Według Jamesa M. Scotta wska-

York, New York 1965, s. 14-19; J. W. BowKER, „»Merkabah « visions and the visions of Paul”, fournal of Semitic Studies 26 (1971), s. 157-173; R. M. PRicE, „Punished in Paradise (An exegetical theory on II Corinthians 12:1-10)" Journal for the Study of the New Testament 2 (1980), s. 33-40. B. H. Young, „The ascension motif of 2 Corinthians 12 in Jewish, Christian and Gnostic texts”, Grace Theological fournal 9 (1988), s. 73-103; A. SEGAL, „Paul and the beginning of Jewish mysticism", [w:] J. J. Collins, M. Fishbane (red.), Death, Ecstasy and Other-Wordly fourneys, Albany 1995, s. 95-122; A. MoRray-Jones, „Paradise revisited (2Cor 12:1-12). The Jewish mystical background of Paul's apostolate”, Harvard Theological Review 86 (1993), s. 177-217, 265-292. J. M. Scott opiera się w tym względzie na: M. HengeL, ,„,Setze dich zu meiner Rechten!“ Die Inthronisation Christi zur Rechten Gottes und Psalm 110,1”, [w:] M. PhiLonenko (red.), Le Trône de Dieu [= Wissenschaftliche Untersuchungen zum Neuen Testament 69], Tübingen 1993, s. 108-194. Autor ten dostrzega więcej przypuszczalnych odniesień do mistyki merkawy w listach Pawłowych.

${ }^{106}$ Martin, 2 Corinthians (cyt. w przyp. 47), s. 398; PACioreK, Drugi List do Koryntian (cyt. w przyp. 48), s. 501-502.

${ }^{105}$ Wallace, Snatched into Paradise (cyt. w przyp. 102), s. 39-168.

${ }^{106}$ Ibidem, s. 286: „Paul's report of his ascent does not simply adopt an understanding from any one text or tradition, nor does he seek to undermine cultural understandings or expectations. Rather, he offers an account of heavenly ascent from the point of view of a follower of a crucified and raised Messiah, which resembles other ascent accounts in many ways but is also distinct".

${ }^{107}$ Inne problemy związane z odczytywaniem 2 Kor 12:2-4 pod kątem mistyki merkawy omawia P. SCHÄFer, „New Testament and Hekhalot literature. The journey into Heaven in Paul and Merkavah mysticism," Journal of Jewish Studies 35.1 (1984), s. 19-35. 
zuje na to Ef 4:8-11, gdyż Paweł cytuje tam właśnie Ps 68:19 w kontekście Chrystusa, który miał wstąpić na wysokość i rozdać ludziom dary duchowe. ${ }^{108}$ Argument ten jednak niewiele dowodzi, gdyż Paweł nic nie wspomina w tym miejscu o Mojżeszu (wstępującym jest dla niego Chrystus), nie poświęca też żadnej uwagi kwestii rydwanu Bożego.

Czy jednak kontekst 2:14 może w jakiś sposób wskazywać na nawiązanie do mistyki merkawy w tym wersecie? Choć autor hipotezy bierze pod uwagę ewentualne cele retoryczne, które Paweł mógłby osiąnnąć poprzez nasz tekst, ${ }^{109} \mathrm{w}$ gruncie rzeczy nie stara się przedstawić, jak obraz związany z mistyką merkawy miałby wynikać z kontekstu literackiego 2 Kor. Autor podchodzi do sprawy od drugiej strony - najpierw zakłada prawdziwość swojej hipotezy i dopiero potem pod jej kątem odczytuje kontekst. Poprzez liczne paralele do literatury żydowskiej pokazuje, że cały passus od 2:14 do 3:18 można z powodzeniem odczytać w kluczu tradycji o Mojżeszu i objawień rydwanu Bożego. ${ }^{110}$ Skoro więc cała interpretacja opiera się na założeniu, że poprzez słownictwo w 2:14 Paweł robi aluzję do tych kwestii, od razu powinniśmy przejść do punktu następnego, by sprawdzić, czy założenie to jest słuszne.

Potencjat wyjaśniający: Sposób rozumowania Jamesa M. Scotta jest nastę-

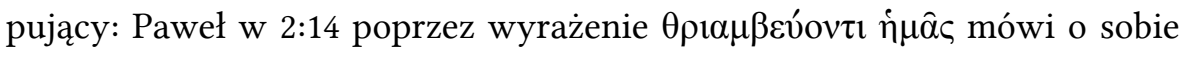
jako o więźniu prowadzonym w rzymskiej procesji triumfalnej. Ten obraz stawia przed oczami czytelnika wyobrażenie kwadrygi, na której jedzie zwycięski wódz. To zaś powoduje skojarzenie z rydwanem Boga. Połączenie wizji merkawy i procesji triumfalnej jest $\mathrm{z}$ kolei aluzją do tradycyjnej interpretacji Ps 68:18-19, według której Bóg zstąpił na świętą górę na swym rydwanie, po czym wstąpił tam Mojżesz, wziął Torę „do niewoli” i przekazał w darze ludziom. ${ }^{111}$

\footnotetext{
${ }^{108}$ Scotr, „The triumph of God” (cyt. w przyp. 95), s. 269.

${ }^{109}$ Według tej interpretacji, 2:14 należy traktować jako rozpoczęcie apologii Pawła. Ponieważ w Koryncie, gdzie wierzący doznawali wielu objawień, podważano jego apostolstwo, Paweł chciałby osiągnąć dwa cele: podkreślić swoje doświadczenia mistyczne oraz ukazać swoją rolę jako pośrednika objawienia Bożego, zob. ibidem, s. 270. Metafora przedstawiająca go w analogii do Mojżesza na Synaju rzeczywiście mogłaby dobrze realizować te cele. Autor jednak nie pokazuje, dlaczego Paweł chciałby zrobić to właśnie w tym miejscu listu.

${ }^{110}$ Ibidem, s. 271-277.

${ }^{111}$ Ibidem, s. 269-270.
} 
Hipoteza ta jednak słabo uzasadnia fakt, że Paweł użył w 2:14 właśnie czasownika $\theta \rho ı \alpha \mu \beta \varepsilon v \omega$. Po pierwsze, brak jest dowodów na to, by objawienia merkawy opisywano przy użyciu słownictwa związanego $\mathrm{z}$ triumfem rzymskim - Paweł musiałby stworzyć oryginalne nawiązanie, przez co odbiorcy mogliby go nie zrozumieć. ${ }^{12}$ Po drugie, czasownik ten oznacza jedynie prowadzenie kogoś lub czegoś w procesji triumfalnej i sam w sobie nie nawiązuje wcale do rydwanu. ${ }^{113}$ Wówczas zrozumienie toku myślenia Pawła zależałoby w całości od dość luźnego, obrazowego skojarzenia, które nie byłoby wcale oczywiste. Po trzecie, poprzez $\theta \rho ı \mu \beta \varepsilon u ́ \omega$ Paweł nie może mówić o sobie jako o Mojżeszu biorącym Torę do niewoli - czasownik wskazuje na to, że Paweł jest najprawdopodobniej w roli jeńca, na pewno nie triumfatora. ${ }^{114}$ Na podstawie powyższych obserwacji możemy sądzić, że jeśli Paweł chciałby rzeczywiście wyrazić to, co przypisuje mu James M. Scott, spodziewalibyśmy się tu dużo bardziej jednoznacznego języka.

Zastrzeżenia budzi również konstrukcja takiej metafory. Jak pisze autor:

When we use a metaphor, we have two thoughts of different things - tenor and vehicle - active together and supported by a single word or phrase, whose meaning is a resultant of their interaction ('two ideas for one'). The 'tenor' is the underlying subject of the metaphor, and the 'vehicle' is the means by which the tenor is presented. ${ }^{115}$

Sposób działania metafory można zgodnie z tym rozrysować jako: „określenie metaforyczne (vehicle) $\rightarrow$ to, co określane metaforycznie (tenor)". W hipotezie Scotta ten schemat musiałby być jednak dużo bardziej skomplikowany - na tyle, że zrozumienie tak wielopoziomowej aluzji byłoby zupełnie niemożliwe:

\footnotetext{
${ }^{112}$ J. M. Scott powołuje się na fakt, że 1QM opisuje ostateczną bitwę nawiązując do rzymskiej wojskowości, zaś późniejsza literatura Hekhalot pisze o Bogu w analogii do cesarza rzymskiego (ibidem, s. 268). Trudno jednak uznać ten argument za wystarczający, jeśli w 2:14 tak daleko posunięte skojarzenie musiałoby być wywołane przez jeden zaledwie czasownik - $\theta \rho ı \mu \beta \varepsilon v ́ \omega$. w roli jeńca musiałby zupełnie odwrócić tradycję o Mojżeszu. Pomija jednak ogromny problem, który z tego wynika - wyrażenie wówczas przestaje komunikować to, co się mu przypisuje.

${ }^{115}$ Ibidem, s. 265.
} 


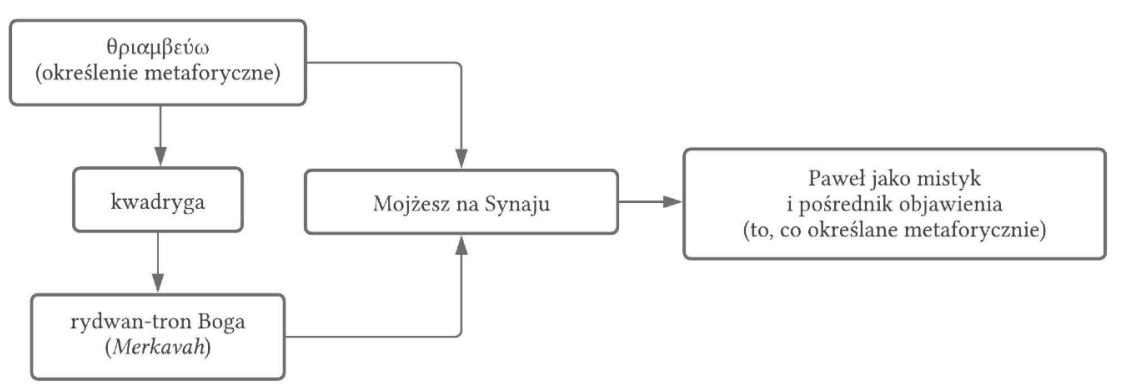

Mamy więc wszelkie podstawy, by uznać powyższą hipotezę za mało prawdopodobną. Bazuje ona na nawiązaniu do triumfu rzymskiego, które samo w sobie jest prawdopodobne, jednakże w tym przypadku autor nadaje mu błędne znaczenie. Drugie zaś nawiązanie - do mistyki merkawy i tradycji o Mojżeszu - zupełnie nie spełnia kryterium potencjału wyjaśniającego i sprawia, że struktura całej metafory jest niepoprawna. Interpretacja Scotta jest jednak o tyle cenna, że pozwala nam przypuszczać, jak Paweł, jako Żyd, mógł w swojej wyobraźni widzieć triumf Boga.

\section{Podsumowanie I WNioski}

Praktyczne wykorzystanie proponowanej tu metodologii pokazało, że jest ona w stanie zadowalająco spełnić wszystkie zadania, jakie jej wyznaczyliśmy. Można z jej użyciem przeprowadzić pełny proces interpretacji metafory i określić, czy propozycja ta jest prawdopodobna; pozwala również na porównanie różnych konkurencyjnych interpretacji tego samego tekstu - dzięki klarownym kryteriom możemy odróżnić hipotezy prawdopodobne od nieprawdopodobnych i ustalić, w którym dokładnie miejscu występują problemy.

Spośród omawianych hipotez tylko hipoteza triumfu rzymskiego spełnia przyjęte przez nas kryteria. ${ }^{116}$ Choć pozostałe na pierwszy rzut oka również

\footnotetext{
${ }^{116}$ Oczywiście istnieją jeszcze inne interpretacje zarówno metafory triumfu, jak i samego czasownika $\theta \rho ı \mu \beta \beta \varepsilon v ́ \omega$, których nie uwzględniliśmy w niniejszej analizie. Zob. np. Field, Notes on the Translation (cyt. w przyp. 21); EGAN, „Lexical evidence” (cyt. w przyp. 21); DAUT-
} 
wydawały się przekonujące, zastosowanie metody Bayesowskiej wykazało, że stojące za nimi przesłanki są niedostateczne. Wynika to z zasadniczego błędu metodologicznego - hipotezy skupiają się na udowodnieniu, że proponowane znaczenie 2:14 pasuje do kontekstu, jednak nie dowodzą tego, że użyte słownictwo faktycznie wskazuje na takie znaczenie (innymi słowy, dowodzą prawdopodobieństwa na podstawie tła, ale niedostatecznie traktują potencjał wyjaśniający). Jeśli zaś chodzi o interpretację tekstu, zasadniczym problemem obu odrzuconych propozycji jest odejście od właściwego znaczenia czasownika $\theta \rho ı \mu \beta \varepsilon v ́ \omega$.

Można wyrazić wątpliwość, czy rzeczywiście każda metafora pod względem struktury da się dopasować do omówionej metodologii. Rzeczywiście, w toku badań napotkaliśmy na taki problem przy hipotezie Jamesa M. Scotta, jednak trudność w tym przypadku wynikała właśnie z tego, że proponowana tam budowa metafory była niepoprawna. Mimo to, udało się wybrnąć z sytuacji i metodologia nawet wtedy okazała się efektywna. Poza tym, największe obawy może budzić to, czy w praktyce zawsze da się osobno analizować tekst na poziomie literalnym i metaforycznym. Okazuje się, że choć całkowite rozgraniczenie tych dwóch poziomów nie zawsze jest możliwe (ani wskazane), to rzeczywiście da się to zrobić bez strat dla procesu egzegezy. Możemy więc powiedzieć, że założenia teoretyczne metodologii sprawdziły się na tej niewielkiej próbie.

Niniejszy artykuł ma także na celu pobudzenie zainteresowania filologów metodami opartymi o twierdzenie Bayesa - z powodzeniem wykorzystuje się je już w różnych gałęziach humanistyki i chcielibyśmy pokazać, że również w naszej dziedzinie może to przynieść znaczne korzyści. Zastosowanie ścisłych kryteriów sprawia, że analiza tekstu przeprowadzana jest w sposób uporządkowany i logiczny - wszystkie działania przebiegają w nieprzypadkowej kolejności i mają z góry ustaloną funkcję. Co bardzo ważne, utrudnia to również pominięcie lub pobieżne potraktowanie ważnych ele-

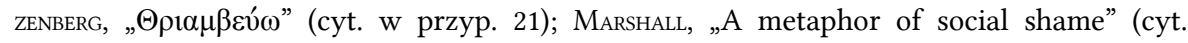
w przyp. 52); W. Weвв, Returning Home. New Covenant and Second Exodus as the Context for 2 Corinthians 6.14-7.1 [= Journal for the Study of the New Testament Supplement Series 85], Sheffield 1993, s. 80-81; A. Носк, „Christ is the parade. A comparative study of the triumphal procession in 2 Cor 2,14 and Col 2,15”, Biblica 88 (2007), s. 110-119. 
mentów dowodzenia. ${ }^{117}$ Poza tym, taka metodologia umożliwia łatwe „przetestowanie" własnej lub cudzej hipotezy, gdyż jasno określa, jakie warunki muszą być spełnione, by hipoteza była uznana za prawdopodobną lub nieprawdopodobną. To wyróżnia proponowane podejście na tle innych metod, które nie są zbudowane w oparciu o rachunek prawdopodobieństwa (np. kryteria Haysa). Ponadto, stosowanie tego rodzaju metodologii na szerszą skalę może pozytywnie wpłynąć na dyskurs naukowy, gdyż z jednej strony pozwala ona dokładnie zlokalizować problematyczne miejsce rozumowania, wokół którego powinna toczyć się dyskusja, a z drugiej strony pomaga unikać bezowocnych rozważań, które nie mają wpływu na prawdopodobieństwo hipotezy. ${ }^{118}$

\author{
Michał Pawikowski \\ ORCID: 0000-0001-5661-2442 \\ Wydział Humanistyczny \\ Uniwersytet im. Mikołaja Kopernika w Toruniu \\ michalpawikowski@gmail.com
}

\footnotetext{
${ }^{117}$ Jak widzieliśmy, nie jest to rzadki problem, gdyż dwie ostatnie analizowane przez nas hipotezy skupiały się na dowodzeniu prawdopodobieństwa na podstawie tła, zupełnie niewystarczająco zaś potraktowały kryterium potencjału wyjaśniającego. Ich autorzy nie dostrzegli tego problemu, jednak stał się on widoczny po zastosowaniu ścisłej metody.

${ }^{118}$ Np. roztrząsania szczegółów potencjału wyjaśniającego, jeśli hipoteza nie spełnia innych kryteriów prawdopodobieństwa.
} 
INTERPRETACJA METAFORY TRIUMFU W 2 KOR 2:14 JAKO PROBLEM METODOLOGICZNY

\begin{abstract}
Abstrakt
Przypadek 2 Kor 2:14-17 ilustruje metodologiczny problem interpretacji metaforyki, która nawiązuje do niejasnego dla nas zjawiska kulturowego. Istnieje potrzeba metody, dzięki której możliwe byłoby: a) zinterpretowanie konkretnej metafory; b) określenie, czy dana interpretacja jest prawdopodobna oraz c) porównanie prawdopodobieństwa alternatywnych interpretacji. W niniejszym artykule autor prezentuje taką metodologię opartą na podejściu Christopha Heiliga: najpierw w postaci teoretycznej, a następnie w praktyce na przykładzie analizy metafory triumfu z 2:14 i trzech wybranych sposobów jej rozumienia.
\end{abstract}

Słowa kluczowe: 2 Kor, triumf, metafora, metodologia, twierdzenie Bayesa

INTERPRETATION OF THE TRIUMPH METAPHOR IN 2 COR 2:14 AS A METHODOLOGICAL PROBLEM

\begin{abstract}
The case of 2 Cor 2:14-17 illustrates the methodological problem of interpreting an imagery that refers to a cultural phenomenon that is not clear to us. There is a need for a method through which it would be possible to: a) interpret a specific metaphor; b) determine whether the interpretation is plausible; and c) compare the plausibility of alternative interpretations. In this article, the author presents such a methodology based on Christoph Heilig's approach: first in theoretical form, and then in practice, using as an example the triumph metaphor in 2:14 and three selected ways of understanding it.
\end{abstract}

Keywords: 2 Cor, triumph, metaphor, methodology, Bayes' theorem 